\title{
Systemic Risk in the Chinese Banking Sector
}

\author{
Eugene Nivorozhkin ${ }^{\mathrm{a}, *}$, Ilias Chondrogiannis ${ }^{\mathrm{b}}$ \\ ${ }^{a} U C L$, School of Slavonic and East European Studies, 16 Taviton St, London, UK, WC1H OBW \\ ${ }^{b} U C L$, School of Slavonic and East European Studies, 16 Taviton St, London, UK, WC1H OBW
}

\begin{abstract}
We examine the evolution and factors of systemic risk in the Chinese banking sector over the last decade from the perspective of international investors. We apply the SRISK measure of systemic risk to a representative sample of listed Chinese institutions that captures $50-60 \%$ of total banking assets and utilize the Granger-causality network-based approach to demonstrate interlinkages among Chinese banks beyond the largest financial institutions. Firstly, we show a dramatic increase in systemic risk after 2011 and the increased contribution of small- and medium-sized banks. Then, we identify causality relationships from housing prices, economic policy uncertainty and shadow banking towards systemic risk and causality from shadow banking to housing prices. According to our results, international concerns about the stability of the Chinese banking system are well justified and a systemic event with international impact could be caused by distress in a Chinese financial institution outside of the group of the largest banks.
\end{abstract}

Keywords: Systemic Risk, Chinese Banking sector, Interconnectedness, Economic Policy Uncertainty, Shadow Banking

JEL Codes: G01, G18, G21, E50

\section{Introduction}

Effective monitoring and control of risks inherited in the financial system and its resilience to shocks received renewed attention in the aftermath of the Global Financial Crisis of 2008.

\footnotetext{
*Corresponding author.

Email addresses: e.nivorozhkin@ucl.ac.uk (Eugene Nivorozhkin), i.chondrogiannis@ucl.ac.uk (Ilias Chondrogiannis)
} 
The ongoing regulatory reform process is still far from over and the adequacy of proposed and implemented financial regulations is subject to heated debate among academics, institutions and practitioners $(\overline{\mathrm{IMF}}(2018))$. Unresolved issues on the post-crisis regulatory reform agenda, adverse feedback loops from volatility in global equity markets on global financial stability, and the buildup of vulnerabilities via risk taking in credit allocation have drawn renewed attention to the importance of internationally coordinated systemic risk assessment and timely policy responses. The efficiency and scope of the existing regulatory mechanisms remains under dispute, since they have not been crisis-tested and hence their effectiveness remains highly uncertain. Although the contribution of the US and the EU banking institutions to global systemic risk tends to dominate the ongoing debate, increasing attention has been paid to their Chinese counterparts, as the large-scale and opaque interconnections of the Chinese financial system is considered to pose stability risks (Williams (2018)).

In this paper, we provide evidence that systemic risk in the Chinese banking sector should be a major source of concern for international investors. We use the MSCI Emerging Markets (MSCI EM) index as the most common international performance benchmark for investment in emerging markets and show that Chinese banks are major contributors of systemic risk to the index. We apply the SRISK measure of Brownlees and Engle (2016) and estimate the systemic risk of Chinese banks as an institution's capital shortfall in response to an emerging markets-wide shock. We show that the propensity of Chinese banks to be undercapitalized when the market as a whole is undercapitalized increased dramatically in recent years, justifying concerns of domestic and international investors and policymakers about market stability. We find that financial institutions smaller than the four biggest banks have become important contributors of systemic risk, in terms of both individual contribution and their effect on the riskiness of other banks. We complement the SRISK results with the Granger-causality network-based approach of Billio et al. (2012) to demonstrate the extensive interlinkages among banks. The relatively smaller banks are more interconnected than the largest banks and those linkages have the potential to act as channels of risk spreading from one institution to another. According to our results, smaller banks have become net contributors of systemic risk and both their absolute and relative importance as well as influence in the financial system has increased in recent years. 
A main contribution of the paper is that we credibly identify economic policy uncertainty, shadow banking and real estate prices as contributing factors to the increase in systemic risk. A series of vector error correction models shows robust uni- and bi-directional causal relationships, both in the long- and the short-run, where SRISK is typically influenced by the Economic Policy Uncertainty index of Baker et al. (2016), the Chinese real residential property price index and two proxies of shadow banking developed in Sun (2019a), a traditional measure based on credit creation and a more general measure of money creation by banks based on accounting statements. In addition, we demonstrate a causal relationship from the shadow banking proxies towards the property price index. This is one of the few empirical results that relate directly the rise in shadow banking to the rise in the real estate prices in China during recent years. We identify the increase in the real estate prices, economic policy uncertainty and the rise in shadow banking as potential sources of an increase in systemic risk and conclude that the influence of shadow banking on the systemic risk of the banking sector to be both direct and indirect via the housing market.

Our main policy suggestion is that the regulatory reforms in the Chinese banking sector must focus not only on the largest banks but on smaller institutions as well. A series of bank insolvencies and government bailouts of banks in recent years ${ }^{1}$ highlight the increased vulnerability of regional banks. We show that a larger number of banks have become more interlinked and carry more clout, which may have important implications for the portfolio diversification strategies of investors. Any government interventions should take into account the complex interactions between policy uncertainty, shadow banking, systemic risk and the real estate market, where systemic risk appears to be the recipient and, sometimes, the distributor, of influence.

\footnotetext{
${ }^{1}$ Some prominent examples after 2013 include financial institutions such as Dalian, Langfang, Inner Mongolia, Jiangxi, Shanxi Qinnong, Jinzhou, Heng Feng, Fuxin and Baoshang.
} 


\section{The financial system and systemic risk in China}

\subsection{Post-2008 crisis developments}

It was apparent from the onset that the massive RMB4 trillion stimulus program, announced by the Chinese government shortly after launching the policy of monetary easing in September 2008, would be channeled to the economy through increased bank lending. As a result, in a relatively short period of time, the assets of Chinese banks increased dramatically from $98 \%$ in 2007 to $109 \%$ of GDP by 2010 for the big four banks, and from $82 \%$ in 2008 to $103 \%$ of GDP by 2010 for the smaller state-owned banks. The overall assets of the Chinese banks reached USD 39.3 trillion, or around 310\% of GDP by 2017 (OECD (2018)). Taking into account the off-balance sheet exposure of banks increases the figure to $387 \%$ of GDP in 2017. Notably, with debt of less than $15 \%$ of GDP, relative to $120 \%$ of GDP in the United States at the onset of the 2008 financial crisis, Chinese financial institutions were largely unaffected by the credit flow disruptions experienced in advanced industrial countries and were in a strong position to increase the supply of credit (Lardy and Subramanian (2011)).

Credit growth tends to be a powerful predictor of financial crises and China is unlikely to be an exception, given the magnitude and speed of its credit boom (Chen and Kang (2018)). China's financial system appears to have all the salient characteristics of a system liable to a crisis such as high leverage, maturity mismatches, credit risk and opacity. The large-scale and opaque interconnections of the Chinese financial system have been emphasized as a continuing threat to the economic stability of the country (IMF (2018)). In particular, the likely transfer of risks across markets and sectors due to the links of Chinese banks to the shadow banking sector and products through their off-balance sheet exposure has recently received a lot of attention (Ehlers et al. (2018)). Preventing and controlling risks, as well as gradually transferring the off-balance sheet capital to the balance sheet in response to tightened regulation has become one of the key priorities of Chinese banks in the past few years.

Recognizing the threats of the shadow banking system, as well as other factors such as a housing bubble, contingent debt of local governments, and their heavy reliance on land sales for financing, People's Bank of China (PBOC) advisers warned that China could face highly 
probable but neglected financial risks (so-called gray rhind ${ }^{2}$ ), reflecting potential threats for the Chinese economy, and proposed measures including direct bailouts of enterprises and bank recapitalization should a crisis hit (Bloomberg News (7 December 2018)).

There is consensus that the Chinese banking sector is subject to systemic risk, yet its sources and magnitude have not been thoroughly assessed. According to Gang and Qian (2015), monetary policy shocks significantly increased systemic risk in the Chinese financial system between October 2008 and November 2013 but had only a limited effect on the real economy. Chen and $\mathrm{Du}(2016)$ argue that, similarly to the US and the EU, financial innovations in China are related to bank stability. Non-performing loans are another potential source of risk, since banks that are more exposed to bad loans are likely to take excess credit risk to cover their losses. This behavior of bank managers may temporarily alleviate the problem of non-performing loans but is likely to increase moral hazard and cause greater losses in the long run due to deterioration in the loan portfolio and institutional stability (Zhang et al. (2016)). Spillover effects have also been considered a prime facilitator of systemic risk in the banking sector (Xu et al. (2018)). Using a network-based approach, Sun (2019b) finds that contagion risk among banks from the default of a single institution is negligible but the network amplification effect of the losses is significant. In a network setup, spillover effects are the main driving factor for bank-specific counterpart risk. Fang et al. (2018) argue that institution size is positively related to systemic risk, indicating that firms with higher market capitalization are more systemically important. However, large banks in China will almost certainly be bailed out by the government during a distress, which lowers their risk contributions during the crisis. This is again consistent with moral hazard, where too-big-to-fail firms accumulate excess risk, knowing that they will receive government support in the case of a capital shortfall.

\footnotetext{
${ }^{2}$ The stress tests conducted by Chinese regulators in early 2014 included a scenario involving banks absorbing losses of 30 per cent on on- and off-balance sheet wealth management products (WMPs) invested in credit assets (though excluding products invested in bonds and deposits). Only one banks capital adequacy ratio fell below 9 per cent (People's Bank of China (2014)). Nevertheless, the channel operations surged dramatically in the subsequent years, so the risk are likely to increase further.
} 


\subsection{Shadow banking and the real estate market in China}

The issue of shadow banking in China has received significant attention in the recent literature. A key result comes from Lai and Van Order (2019), who identify a relationship between shadow banking, proxied by loans from non-banking financial institutions, and house prices using Pooled Mean Group estimation in 65 Chinese cities. The authors find that house prices grow more rapidly with availability of shadow banking funds, which grew rapidly over the 2006 - 2015 period. This provides empirical support to our hypothesis of a link between the observed increase in Chinese real estate prices and the reported rise in shadow banking activities. We expand on these earlier results by using quarterly data on the magnitude of shadow banking from Sun (2019a) to examine causal relationships between the housing price index, shadow banking and systemic risk, among others.

The issues related to Chinese shadow banking are similar to those identified in developed economies, with some specific features due to the country's distinct characteristics Hachem (2018) for a comprehensive review). Securitization and structured investment products increasingly complement the basic functions of asset offloading, regulatory circumvention and maturity mismatch (Ehlers et al. (2018)). When regulated banks act as intermediaries, such as for firm-to-firm entrusted loans, they are not burdened with additional risk (Allen et al. $(2019))$. However, when own securities are sold, the final bearer of risk is unclear. Indicatively, Tian et al. (2016) find that the trust companies were the main source of instability in the Chinese financial system as a whole between 2007 and 2012, and commercial banks suffered the most from its adverse effects. The recent regulatory crackdown seems to have halted the growth rate of the sector, but at the same time increased concerns on profitability, liquidity and non-performing loans (Financial Stability Board (5 March 2018)). Importantly, the lack of data and disclosed information, as well as the variety of definitions, make any discussion around shadow banking rather ambiguous.

The relationship between shadow banking and the real estate sector appears to be of particular interest. Real estate has become a hub of Chinese domestic interlinkages and the

final collateral of multiple financing. It is estimated that about $20-25$ per cent of assets of 
pecuniary funds are channeled to the real estate sector ${ }^{3}($ Liao et al. $(2016))$. Although not as important as that of the financial sector, the risk exposure is significant and the distress of an important construction firm, with a typically high credit rating, can put pressure on the shadow banks which tend to hold short-term bonds from the construction sector. Ding et al. (2017) identify links between real estate and shadow banking. The exposure of banks to the real estate sector is argued to be moderate, but protective barriers are being eroded. Shadow banking in China surged dramatically because the traditional banking system was not structured to accommodate the needs of an increasingly expanding and complex market. Therefore, agents in need of credit, such as real estate firms and private borrowers, increasingly use new, non-traditional channels, to obtain debt financing (Elliott) et al. (2015)).

\subsection{Economic Policy Uncertainty in China}

Economic Policy Uncertainty (EPU) indices based on press coverage of economic news have recently become a popular tool to analyze and forecast stock market risk and returns. Recent findings suggest that these indices can improve volatility forecasting and are positively related to market volatility (Liu and Zhang (2015)). Research focusing on China commonly connects EPU with stock market movements, where EPU tends to be strongly negatively correlated with stock market returns (Yang and Jiang (2016)), or deals with the construction of an appropriate EPU index (Huang and Luk (2020)). However, the literature offers little discussion on the relationship between news coverage and public sentiment, as captured by such an index, and systemic risk. An exception to this are Sun et al. (2017), who detect varying correlations and both uni- and bi-directional spillovers between systemic risk and policy uncertainty in the US. This is the gap we intend to cover, by using the EPU and Trade Policy Uncertainty index (Baker et al. (2016) ) which covers business and economics news published in the Hong-Kong based South China Morning Post. It can serve as an indicator of public sentiment which represents qualitative rather than quantitative shifts (Stolbov et al. (2018)) and international investors are expected to be more attuned to it.

\footnotetext{
${ }^{3}$ A comprehensive summary for the Chinese real estate market can be found in Koss and Shi (2018).
} 


\section{Data and methodology}

\subsection{Indicators of systemic risk in banking}

Market-based measures of bank systemic risk attempt to incorporate the views of market participants and can be very useful for assessing whether market participants and regulators agree on the relative systemic importance of individual domestic banks. Within the broad range of Value-at-Risk (VaR) and expected shortfall measures used to assess systemic risk, we select SRISK (Brownlees and Engle (2016), Engle et al. (2014)). Fang et al. (2018) provide evidence that the systemic risk measures partially based on book values, such as SRISK, are relatively more accurate than measures relying only on market values, which makes our approach appropriate for the Chinese banking sector. SRISK provides an estimate of how much capital a financial institution would need given a severe distress of the entire stock market. The market-based nature of the measure allows us to examine the effect of a drop in the performance of emerging markets and relate it to the performance of Chinese banks. Since the MSCI EM index provides international investors with a readily available performance benchmark, as well as a representative tool for a wide selection of countries, our adopted methodology captures both the exposure of an investor in emerging markets to the riskiness of the Chinese banking sector as well as the systemic role of those financial institutions.

During stock market declines, the financial system as a whole can be considered as undercapitalized, which makes the undercapitalization of an individual bank more difficult to be absorbed by the market. Therefore, banks which lack capital in such a situation are more likely to require additional funding, bailouts or could even experience bankruptcy. Such funding requirements are closely related to negative externalities (Acharya et al. (2017)), as the VaR of an individual firm affects the VaR of the entire system Adrian and Brunnermeier (2016)). Thus, SRISK shows not only the capital shortfall of an individual firm, but also the firm's contribution to the total systemic risk of the sector. It captures firm distress conditional on a market crisis and is found to have some predictive power (Brownlees and Engle (2016)). For bank $i$ at time $t$ and for a time interval $T$, the banks need for additional capital, or capital shortfall, is defined as 


$$
C S_{i, t: t+T}=E_{t}\left(\theta A_{i, t+T}-W_{i, t+T} \mid C_{t: t+T}\right)
$$

Where $\theta$ is the prudential capital ratio (minimum capital requirements), $A$ the value of assets, $W$ the bank's market capitalization and $C$ the crisis threshold, or the threshold below which the market has fallen enough to be considered in distress. $C S$, therefore, shows how much capital a bank requires if market distress occurs in order to cover the amount $\theta A$ required by the regulator, given its market valuation. Market capitalization (market value of equity) is used instead of the book value of equity as a proxy of firm value, due to its daily frequency and its dependence on stock price fluctuations, which allows the conditional returns forecast of the test. The total value of assets is proxied by the quasi-value of assets $B A+W-B E$, where $B A$ is the book value of assets and $B E$ the book value of equity. Quasi-market values are used as a reasonable compromise between book and market values of the different variables (Engle et al. (2014)), while the formulation of the test based on assets rather than debt addresses issues of data accuracy since reported assets are more reliable than reported debt. We set the distress threshold $C$ to $-10 \%$ on a monthly basis. Finally, the prudential capital ratio is set to $10 \%$. The value of bank debt $D$ is proxied as the difference between the book values of debt and equity $(D=B A-B E)$, and is considered to remain constant within the observed time intervals. If leverage is defined as $L_{i, t}=A_{i, t} / W_{i, t}$, then $D_{i, t}=\left(L_{i, t}-1\right) W_{i, t}$ and CS becomes $C S_{i, t: t+T}=\theta\left(L_{i, t}-1\right) W_{i, t}(1-\theta) E t\left(W_{i, t+T} \mid C_{t: t+1}\right)$.

The last term can also be expressed as the percentage change of market capitalization of a bank conditional on market distress. Taking $W_{i, t}$ out as a common factor, conditional capital shortfall for bank $i$ can be defined as

$$
C S_{i, t: t+T}=W_{i, t}\left(\theta\left(L_{i, t}-1\right)-(1-\theta) E_{t}\left(1-L R M E S_{i, t: t+T}\right)\right)
$$

where

$$
L R M E S_{i, t: t+T}=-E_{t}\left(R_{i, t: t+T} \mid R_{M, t: t+T} \leq C_{t: t+T}=-10 \%\right)
$$

\footnotetext{
${ }^{4}$ The Chinese regulatory framework is stricter than the Basel III provisions, with a minimum capital requirement at $8 \%$, a $2.5 \%$ capital conservation buffer, an extra $1 \%$ surcharge for Systemically Important Financial Institutions and a $0-2.5 \%$ counter-cyclical buffer. A reduction of $0.5 \%$ was applied in 2018 to certain institutions. As compromise across the sample, we adopt a total prudential capital ratio of $10 \%$.
} 
LRMES is the long-run marginal expected shortfall of bank $i$ for interval $T$ between time $t$ and $t+T$, or the percentage reduction in market capitalization. Default occurs when LRMES = 1, where market capitalization is zero. $R_{i, t: t+T}$ and $R_{M, t: t+T}$ are the simple returns over period $T$ (set to one month) for bank $i$ and the market, respectively, based on cumulative log-returns calculated by the forecasting model. Forecasts for LRMES are obtained via GARCH-DCC, following Brownlees and Engle (2016).

The final form of the test is

$$
S R I S K_{i, t: t+T}=\max \left(0, C S_{i, t: t+T}\right)
$$

or positive capital shortfall. It measures the equity buffer that would be sufficient to overcome a possible financial crisis. SRISK estimates for individual banks can be summed to produce aggregate SRISK for the sample, which in our case is a reliable proxy for the Chinese banking system since the largest and most important financial institutions are included. The fraction of a banks SRISK over aggregate SRISK allows us to calculate the percentage contribution of each bank to the total.

\subsection{Interconnectedness measures}

In a fully efficient market, equity price changes would be random, hence a Granger causality test would not detect any causal relations in returns. However, in the presence of VaR constraints or other market frictions, such as transactions costs, borrowing constraints, costs of gathering and processing information, and institutional restrictions on short sales, we may find Granger causality among equity returns. Moreover, this potential forecastability cannot be easily arbitraged away, precisely because of the presence of these frictions. From this perspective, the degree of Granger causality in asset returns can be viewed as a proxy for spillovers among market participants (Danielsson et al. (2010)). The greater spillover effects imply stronger connections and integration among financial institutions, heightening the severity of systemic events.

In a Granger causality framework one can determine the directional return spillovers in the financial system (composed, in our case, of 17 Chinese banks). Time series $j$ Granger- 
causes another time series $i$ if the information contained in the past values of $i$ and in the past values of $j$ are more useful in predicting the value of $i$ than the information based only on the past values of $i$. Formally,

$$
(j \rightarrow i)= \begin{cases}1, & \text { if } j \text { Granger-causes } i \\ 0, & \text { otherwise }\end{cases}
$$

and $(j \rightarrow j) \equiv 0$. Thus, based on these pairwise Granger causalities, one can construct the Granger-causality network. The network in our case is defined as a set of 17 nodes connected by edges. The size of each node is defined relative to the average market capitalization of a bank over the sample period ${ }^{5}$. The network can be represented as an $N_{t^{-}}$dimensional adjacency matrix $A_{t}$ with the elements $\alpha_{i j t}$ taking values of zero and one, with $\alpha_{i j t}=1$ if node $j$ Granger-causes node $i$ and $\alpha_{i j t}=0$ otherwise. Following Billio et al. (2012), the returns are modelled using a $\operatorname{GARCH}(1,1)$ process. We focus on the following measures of connectedness, where $\alpha_{i j}$ denotes a causal connection between banks $i$ and $j$

The Dynamic Causality Index (DCI) is defined by the following expression:

$$
\left(\begin{array}{c}
N_{t} \\
2
\end{array}\right)^{-1} \sum_{i=1}^{N_{t}} \sum_{j=1}^{N_{t}} \alpha_{i j t}
$$

and denotes the number of statistically significant Granger-causality relationships among all $\mathrm{N}(\mathrm{N}-1)$, or $17 \times 16=272$ pairs of $\mathrm{N}=17$ financial institutions over time.

The In+Out (IO) and In+Out-Others (IOO) network degrees is defined by:

$$
I O_{t}^{i}=\sum_{j=1}^{N_{t}} \alpha_{i j t}+\sum_{i=1}^{N_{t}} \alpha_{j i t}
$$

The first part of the right-hand side of the relationship is the IN network degree and measures the number of return series $i$ that significantly (at 5\% significance level) Grangercause institution $j$, whereas the last part of the right-hand side of the relationship is the OUT

\footnotetext{
${ }^{5}$ More specifically, average market capitalization is calculated over the sample for all banks. The average of each bank is then divided by the mean of all averages. The resulting weights are normalized between 0.2 and 4 for illustration purposes.
} 
network degree and measures the number of return series $i$ that are significantly Grangercaused by institution $j$. We group our sample into the Big 4 banks (Bank of China, Industrial Commercial Bank of China, China Communications Bank, Agricultural Bank of China) and all other banks. In+Out-Others is the number of return series of other types of firms (Big 4 or all others) that significantly Granger-cause return series $j$ and are significantly Grangercaused by it. Therefore, IOO is essentially a form of IO conditional on the group of a bank and indicates the effect of banks belonging to a particular group. Degree centrality represents the number of connections (degree) in each node. We report the number of connections that are Granger-caused by that bank as well as the number of total connections to the bank, in order to determine whether the bank is affected by more banks than those it affects.

\subsection{Data}

We collect daily returns and market capitalization data from Thomson Reuters Datastream, for a set of 17 listed Chinese banks (Table 1) and the MSCI EM index. The quarterly data on total assets and shareholder equity is obtained from Compustat and complemented by Thomson Reuters Eikon data when necessary 5 . The Economic Policy Uncertainty and real residential property prices indices come from the Economic Policy Uncertainty website and the Bank for International Settlements (retrieved from FRED, Federal Reserve Bank of St. Louis) respectively. We also report abbreviations and the date at which data becomes available. The number of observations is before interpolation is applied and for the maximum period available. The Traditional Shadow Banking and Bank Shadow values are taken from Sun (2019a) and converted to billion US dollars by using the end-of-month exchange rate. All amounts are in US dollars and the banks have been selected based on the size and the availability of quarterly data. We assume that although an investor would have access to both A-listed and H-listed shares, she would invest in $\mathrm{H}$-shares where available since they are more attuned to international markets. In order to check for sample selection issues, we conducted the same exercises using A-shares only and the MSCI-EM index as international benchmark. There was no virtual change in our results. We also used the

\footnotetext{
${ }^{6}$ Missing data points are interpolated from semi-annual observations in a small number of cases.
} 


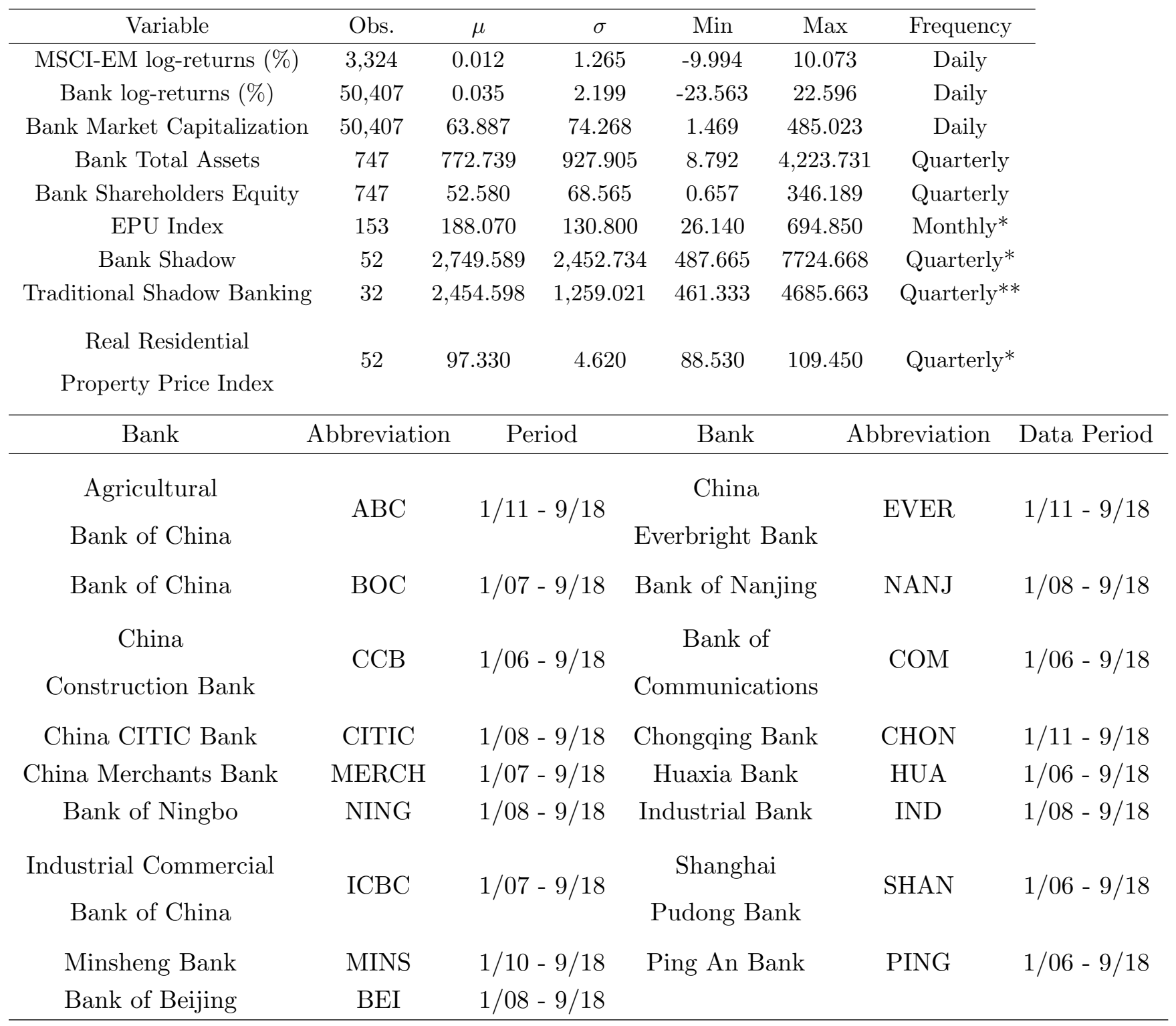

TABLE 1

Sample summary statistics

Note: Non-index values in billion US dollars. Periods: (*) January 2006 - September 2018 (**) January 2011 - September 2018. Obs. before interpolation where applicable.

domestic Datastream stock market index for China, which is more representative for Chinabased investors with a domestic focus, instead of the more general MSCI-EM. Our results 
were, again, robust, and are available upon request for both cases. For brevity, we focus our analysis on an international investor who uses the MSCI-EM benchmark and invests in Aand H-shares.

"Bank Shadow" (BSHADOW) and "Traditional Shadow Banking" (TRADSB) refer to the shadow banking proxies covered in Sun (2019a). The Traditional Shadow Banking measure is defined as credit creation by non-bank financial intermediaries through money transfer, while Bank Shadow is defined as money creation by banks through accounting treatments that generate liabilities, and moves beyond traditional loans. TRADSB is the sum of (i) the claims of financial companies on non-financial companies and households (ii) balance of finance lease contracts (iii) balance of microfinance company loans, and (iv) balance of trust assets, excluding bank trust cooperation. The last category is by far the largest component of the sum. BSHADOW is calculated as M2 plus government deposits (which is negative) plus capital accounts minus the sum of loans, foreign exchange business and corporate bonds holdings. The quarterly data is interpolated to monthly frequency similar to the real residential property price index.

\section{Empirical results}

\subsection{Systemic risk results}

SRISK is estimated individually for each bank in our sample with the MSCI EM index used as the market proxy. We report aggregate SRISK results. Figure 1a presents SRISK when all banks in the sample are included irrespective of when they enter the sample. Starting from 01-01-2006, the SRISK estimate for a bank is included to the total when the data becomes available. While between 2006 and 2011 systemic risk is almost zero, it starts increasing rapidly in the following years. A brief reduction is observed in 2013 and a large dip in 2015, after which systemic risk remains consistently high and gradually decreases until it surges again in early 2018 to its most recent peak of USD 900 billion. The overall observed pattern is very clearly one of increased risk in the financial system, which coincides with our earlier

observations on the effect of the Chinese monetary policy on systemic risk. It also agrees 


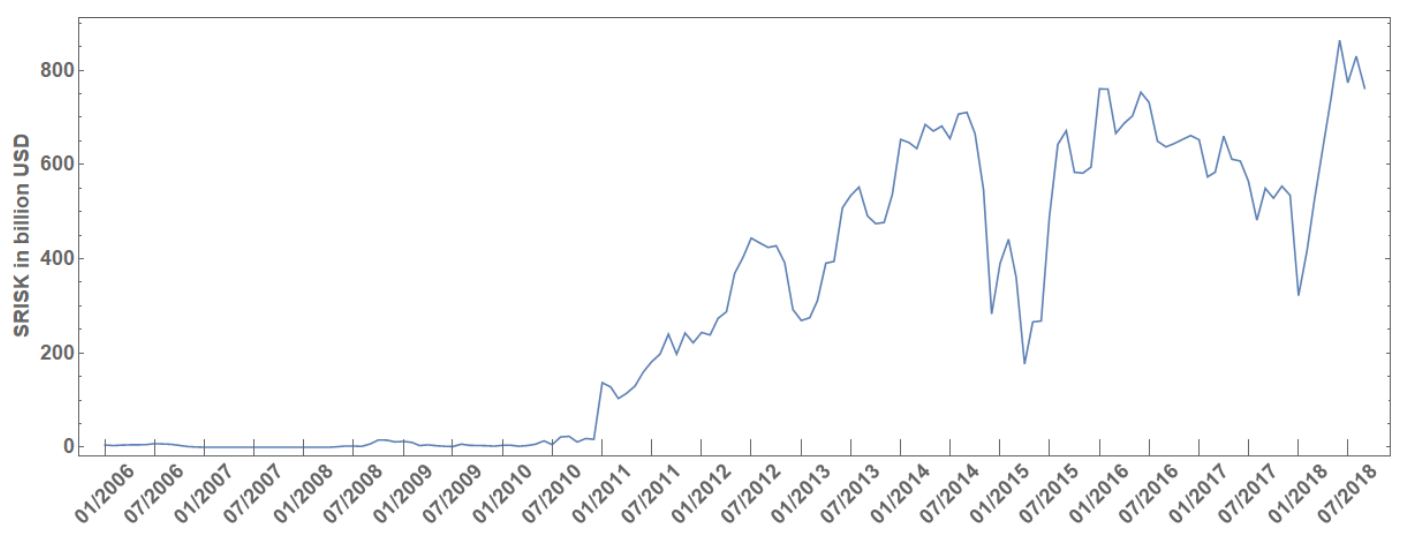

(a) Aggregate SRISK for all banks

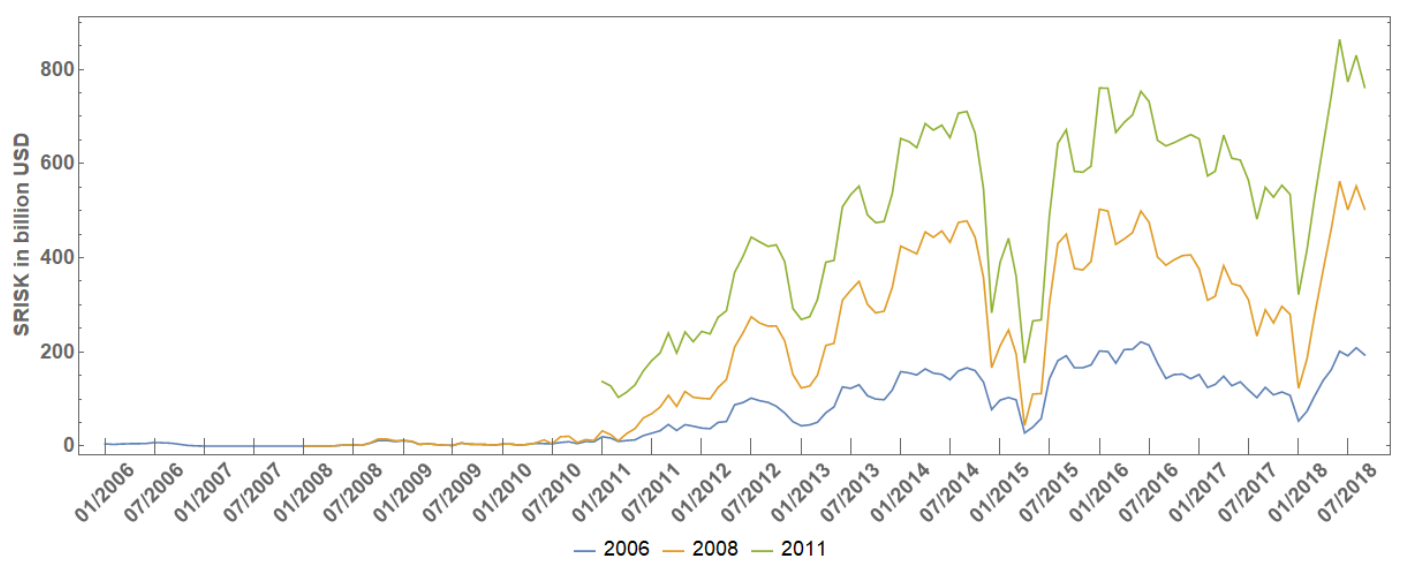

(b) Aggregate SRISK according to year of data availability. 2006: CCB,

BoComms, Huaxia, Ping An, Shanghai Pudong. 2008: BoC, ICBC, Merchants, CITIC, Beijing, Nanjing, Ningbo, Industrial. 2011: Minsheng, ABC, Everbright, Chongqing

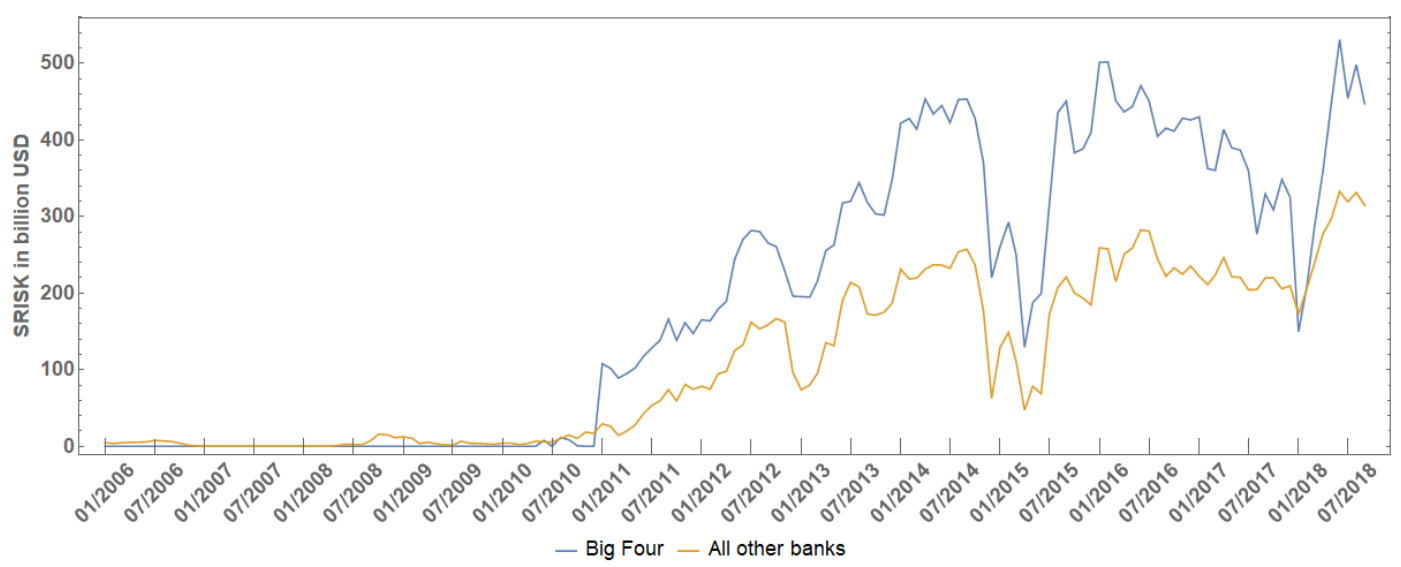

(c) Aggregate SRISK of the Big Four (CCB, BoC, ICBC, ABC) and all other banks

FIGURE 1 
with findings that the financial crisis did not affect the Chinese banking system as much as the US and the EU (IMF (2018)). The 2006 - 2011 sample includes 14 out of 17 banks, all of which are globally or systemically important and sufficiently large (apart from the Agricultural Bank of China, which underwent IPO in 2010, so the data becomes available in 2011). The Chinese banking system was resilient to the direct financial effects of the 2008-09 global financial crisis, in large part because it was focused on a strongly growing domestic market and had little exposure to overseas wholesale funding markets. The large surge in SRISK during 2011 - 2012 coincides with the end of the 2008 economic stimulus package, which led to a surge in credit volume and asset prices. The 2015 and 2016 Chinsese stock market crashes are also associated with the large SRISK increase between May 2015 and August 2016. The next large increase of SRISK in 2018 can be attributed to a combination of factors such as the crackdown on shadow banking.

Figure 1b separates banks into three categories, given the most inclusive starting points: 11 - 2006 (5 banks), 1 - 1 - 2008 (8 banks) and 1 - 1 - 2011 (4 banks). The trends are largely similar to those in Figure 1a. Importantly, it appears that limited data availability for earlier dates in our sample does not affect the observed general trend. Although the majority of banks are already present in the sample in 2008, the observed SRISK remains negligible. The increase in SRISK is visible in 2011 for all of the three "inflow" categories of banks, which further supports our insights. This allows us to ignore the starting dates and use the aggregate indicator reported in Figure 1a.

Figure 1c shows the SRISK evolution of the four biggest Chinese banks (Industrial Commercial Bank of China - ICBC, Agricultural Bank of China - ABC, Bank of China - BoC, China Construction Bank - CCB) and all other banks in our sample, in absolute and percentage terms. The Big 4 are the main drivers of systemic risk. This group's contribution to SRISK peaks at USD 540 billion, while all other banks combined peak at USD 340 in early 2018. The individual trends of the banks are consistent with the aggregate trend (Figure 1a), showing that the sector behaves in a surprisingly uniform way. Crucially, the percentage contribution of the Big 4 to aggregate SRISK gradually decreases between 2011 and 2018 while the aggregate SRISK of all other banks increases, leading to a 60-40\% split in 2018 (Figure 2a). This highlights the increased importance of the wider banking sector rather 
than an improvement of the risk exposure of its flagship institutions. The increasing SRISK contribution of smaller banks becomes more obvious in recent years. The most important contributor of systemic risk for the entire system is $\mathrm{ABC}$ (Figure 2b), which is both the bank with the highest SRISK and the one with the most SRISK fluctuations. The percentage scale implies that $\mathrm{ABC}$ was practically the only bank contributing to SRISK at that time. This is not surprising, given the historically large amount of non-performing loans ABC accumulated (Li et al. (2014) ). ICBC and CCB move at the same levels and follow the pattern most of the time after 2011.

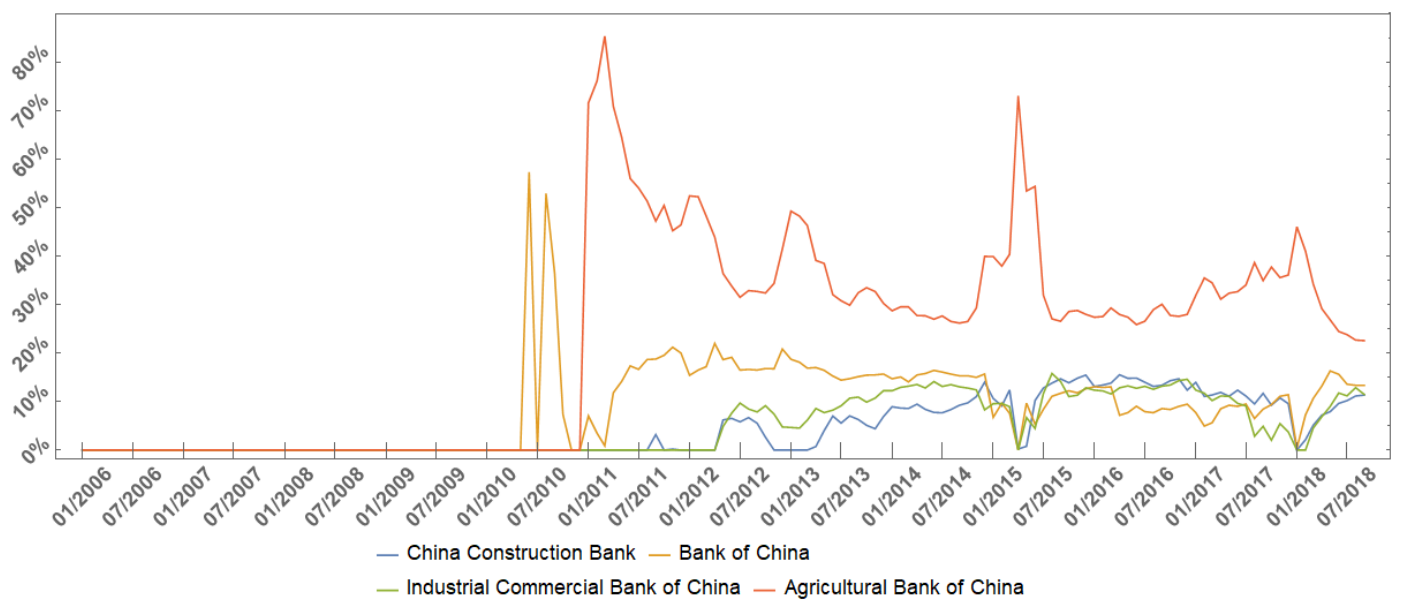

(a) Contribution (\%) of each of the Big Four banks to total SRISK

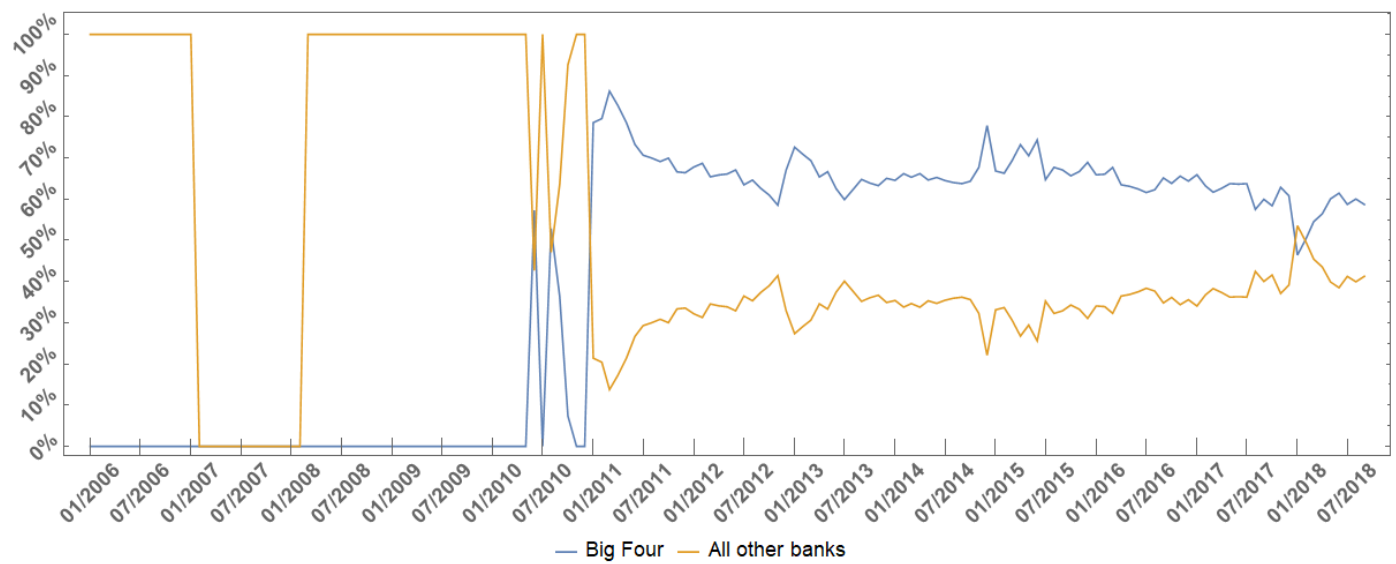

(b) Group contributions (\%) to total SRISK of the Big Four and all other banks

FIGURE 2 
Finally, Figure 3 shows the contribution of all banks to total SRISK between 2012 and 2018. Banks with contribution lower than $3 \%$ are added together. The results strengthen the insights gained from the aggregate trends, as they appear to hold for individual banks as well. While the SRISK of ABC dominates every year, the contribution of the other three biggest banks is by no means negligible. With small exceptions, each bank in our sample contributes between 10 and 15 percent of the total. The contribution of smaller banks constantly increases as a total but, individually, they generally contribute below 7-8\%. A percentage increase implies a shifting of risk across banks but does not prevent a reduction of systemic risk in total, which is in line with our interconnectedness results. Overall, the largest institutions are the main contributors of systemic risk with many smaller banks contributing to a lesser degree. However, all banks appear to be net contributors at some stage, albeit limited. This is a worrying finding when compared to SRISK results for the US banks (Brownlees and Engle (2016)). SRISK in the US between 2005 and 2011 depended almost entirely upon a small number of market leaders, most of which were bailed out or went bankrupt, such as Fannie Mae, Freddie Mac and Lehman Brothers. Notably, the SRISK estimate for those three institutions ranged between 8 and $9 \%$ of total SRISK, only slightly higher than the estimates for the non-Big 4 Chinese banks. This indicates two things for the Chinese banking system. Firstly, an institution may still cause a systemic event even if its SRISK is relatively low. Secondly, a larger number of banks is capable of causing a systemic event.

Our results indicate that systemic risk is widely spread in the Chinese financial system, leaving no bank unaffected. The most important banks are also likely to be the most undercapitalized ones in the case of a market distress. The part of systemic risk allocated to the smaller banks of our sample currently stands at $40 \%$ and increasing, but the segment attributed to the smallest contributors (sum of systemic risk below 3\%) has increased from $6 \%$ to $13 \%$ in the last years. This matches observations that mid-tier and regional banks have become riskier, as demonstrated by a series of bailouts in this market segment. The rapid increase of SRISK after 2012 can be attributed to excessive risk taking, an increasing amount of non-performing loans, high interest rate spreads and significant expansion in credit volume, primarily from cross-regional banks (Zhu et al. (2019), Zhang et al. (2018)). 

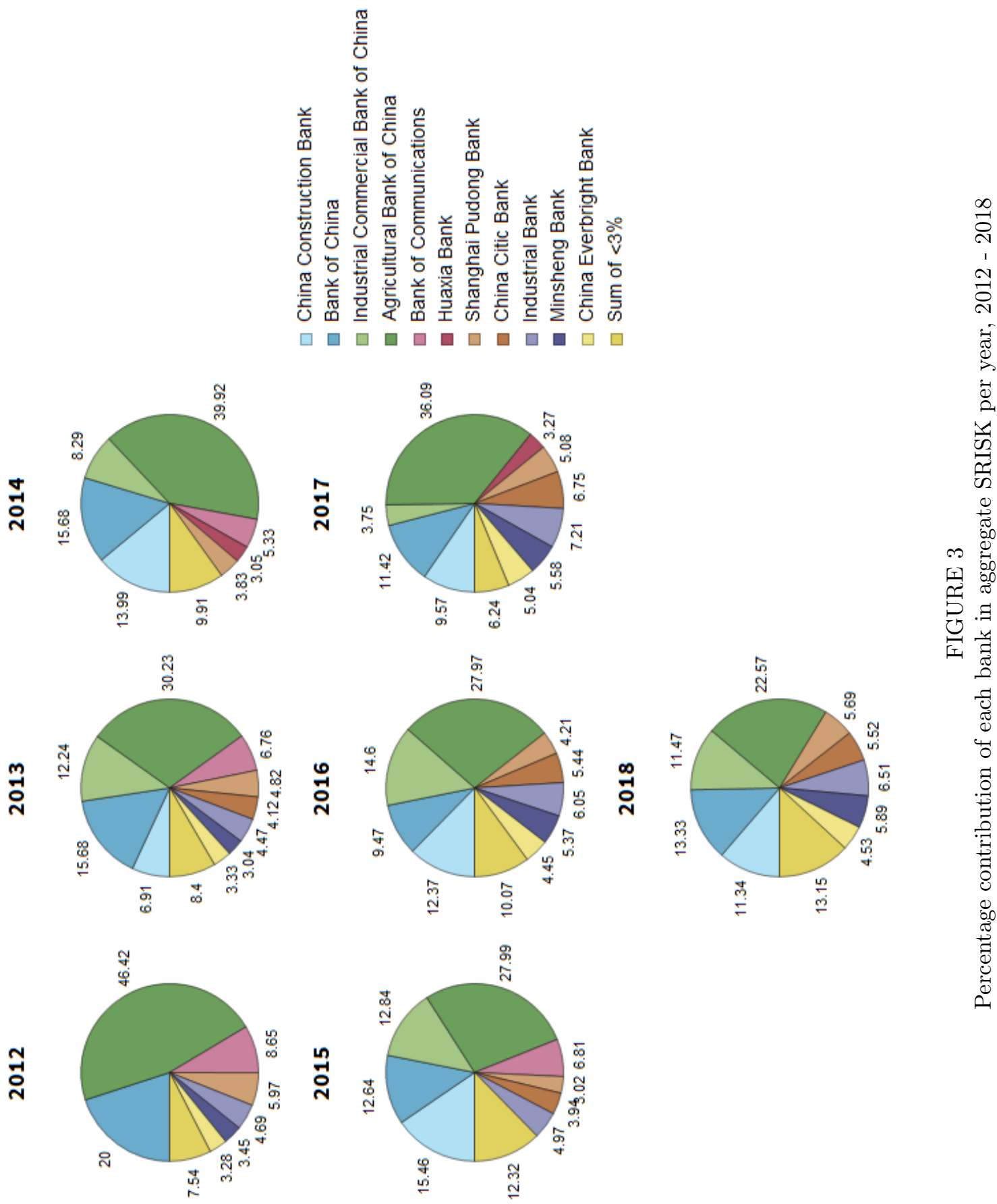

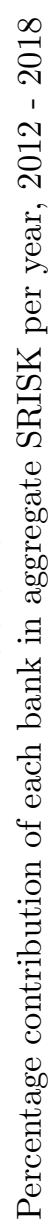


Using a sample of Chinese commercial banks between 2006 and 2010, Qian et al. (2015) suggest that government ownership has no effect on prudential bank behavior, while having government officials appointed as board directors has a negative effect. In addition, high bank capital requirements are likely to increase risk-taking after a certain level (Jiang et al. (2019)).

A small value of SRISK may well represent a loss of capital enough to put the bank under distress, which can cause contagion. Our findings are in line with industry and academic observations on the riskiness and interconnectedness in the Chinese financial system. They are also consistent with the literature discussed earlier on the paired relationships between the real estate market, banks and the shadow banking sector. The increase in systemic risk also matches the observed trends in bank consolidation and a general reduction in the number of banks in China.

\subsection{SRISK, real estate prices, shadow banking and policy uncer- tainty}

Our results on the systemic risk of Chinese banks indicate a strong upward trend over time and significant changes in the distribution of individual contributions of the banks. The literature discussed earlier in the paper also suggests that the growing shadow banking sector, the soaring housing prices, and an increase in economic policy uncertainty are likely to be positively associated with systemic risk. Figures $4 \mathrm{a}$ and $4 \mathrm{~b}$ depict the real residential property prices (housing price index) for China together with the aggregate SRISK plot and the Hong Kong-based EPU index, along with aggregate SRISK together with the traditional

shadow banking and bank shadow indicators. The housing price index peaked in 2018 and has been growing rapidly after 2015, in a manner similar to SRISK. Moreover, the joint plot reveals that after 2011 when SRISK first increased, the index follows the evolution of systemic risk while prior to that they appear to be unrelated. EPU moves closely with SRISK after 2015, a period which coincides with two stock market crashes in China. Similar trends are observed between the SRISK and shadow banking indicators.

We hypothesize that all of the discussed indicators contribute to the rise in systemic 


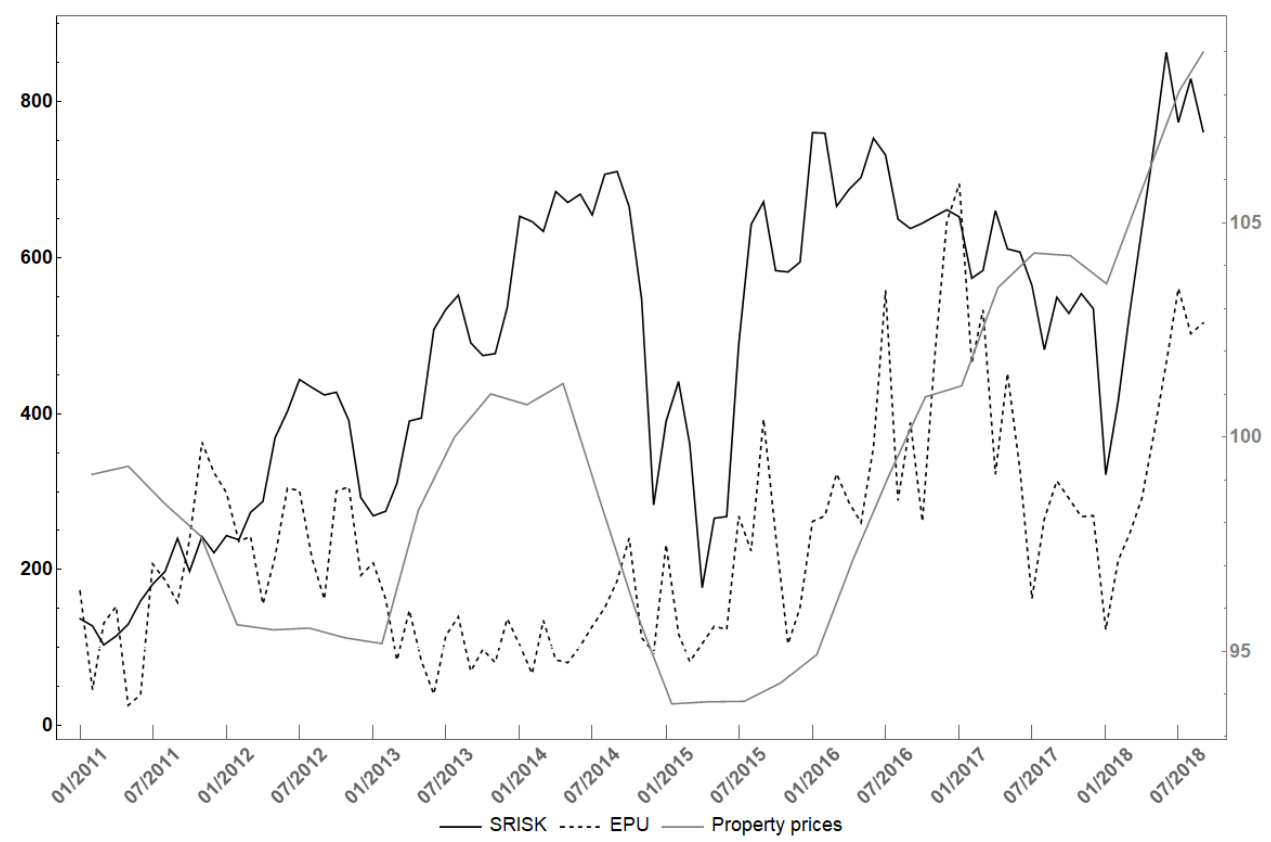

(a) Original data of SRISK, EPU index (Hong-Kong based) (left axis, black) and real residential property prices index (right axis, grey), 1-2011 - 9-2018.

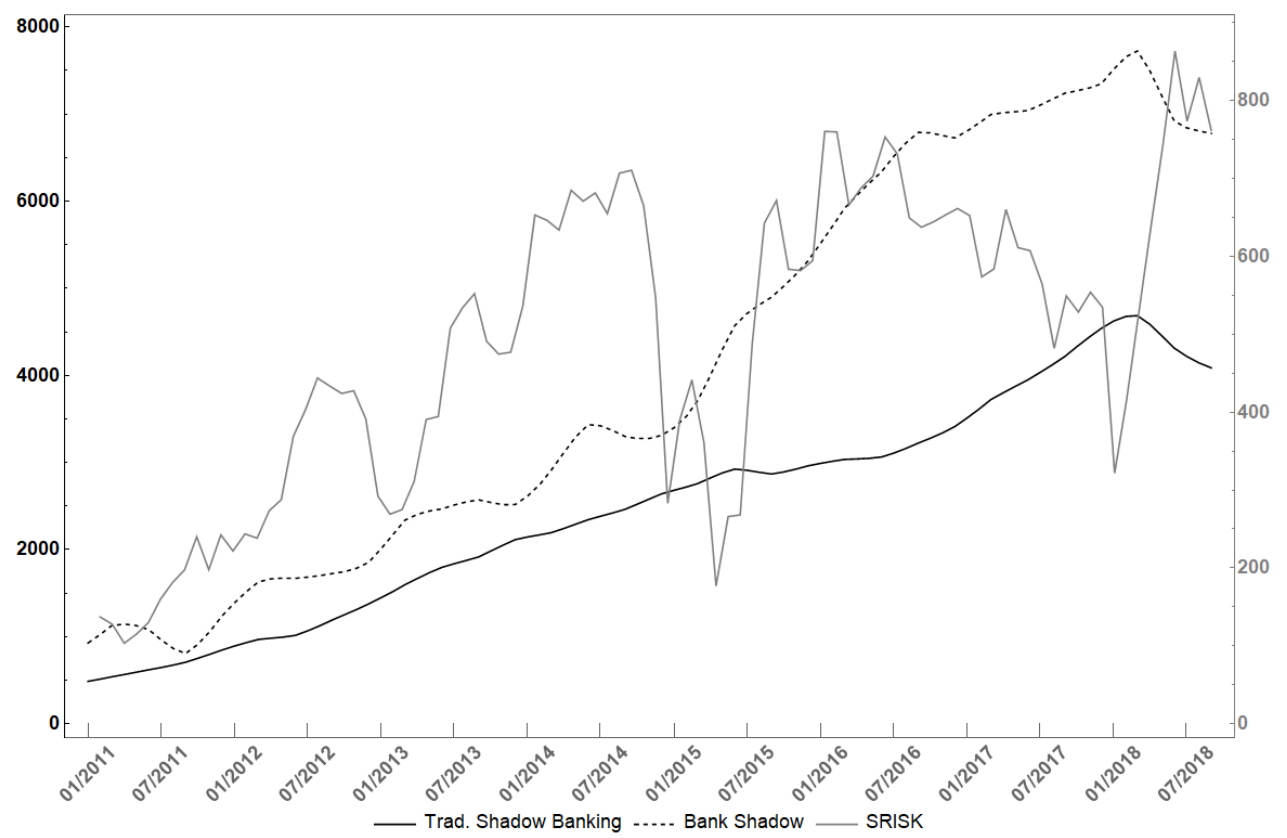

(b) Original data of SRISK (right axis, grey), Traditional shadow banking and Bank Shadow (left axis, black), 1-2011 - 9-2018

FIGURE 4 


\begin{tabular}{cccccccc}
\hline \multirow{2}{*}{ Variable } & AR Model & Lags & $\begin{array}{c}\text { Test } \\
\text { statistic }\end{array}$ & $\begin{array}{c}\text { Test stat. } \\
\text { (1st diff.) }\end{array}$ & $1 \%$ c.v & $5 \%$ c.v & $10 \%$ c.v \\
\hline SRISK & $\begin{array}{c}\text { Drift and } \\
\text { det. trend }\end{array}$ & 1 & -3.062 & -6.701 & -4.066 & -3.462 & -3.157 \\
EPU & $\begin{array}{c}\text { Drift and } \\
\text { det. trend }\end{array}$ & 2 & -2.327 & -6.750 & -4.067 & -3.462 & -3.157 \\
PROPP & $\begin{array}{c}\text { No drift, } \\
\text { no det. trend }\end{array}$ & 1 & 0.6502 & -2.6502 & -2.592 & -1.945 & -1.6139 \\
TRADSB & $\begin{array}{c}\text { Drift and } \\
\text { det. trend }\end{array}$ & 1 & -1.2370 & -4.4129 & -4.066 & -3.462 & -3.157 \\
BSHADOW & $\begin{array}{c}\text { Drift and } \\
\text { det. trend }\end{array}$ & 1 & -3.2560 & -6.4496 & -4.066 & -3.462 & -3.157 \\
\hline
\end{tabular}

TABLE 2

Augmented Dickey - Fuller tests

Note: All series in natural logarithms. SRISK is in billion \$US, EPU is Hong Kong based EPU index, PROPP is the real residential property price index (monthly after cubic interpolation). EPU and PROPP indexed at January 2011. Lags based on correlogram of residuals. Tests without drift and with drift but no deterministic trend also fail.

risk between January 2011 and September 2018. We examine cointegration and causality between systemic risk (SRISK), the Chinese real residential property price index (PROPP) (or "housing price(s)"), the Economic Policy Uncertainty index, traditional shadow banking (TRADSB) and bank shadow (BSHADOW). This allows us to shed further light onto the interplay between the real estate market and the shadow banking sector, an issue that, with the exception of Lai and Van Order (2019) has been studied indirectly only.

\subsubsection{Systemic risk and policy uncertainty}

A series of Augmented Dickey-Fuller tests (Table 2) shows that all series are I(1) at levels and become stationary after taking first differences. A Johansen cointegration test (Table 3), which is more suitable for small samples, is conducted for all pairs and groups of the time series at the variable levels. Following Turner (2009), we use the MacKinnon et al. (1999) critical values because they are the most robust if there is a mismatch between the critical values used and the specification of the vector error correction model (VECM). The starting 


\begin{tabular}{|c|c|c|c|c|c|c|c|}
\hline Variable & Model & Lags & Rank & $\begin{array}{c}\text { Trace } \\
\text { statistic }\end{array}$ & $1 \%$ c.v & $5 \%$ c.v & $10 \%$ c.v \\
\hline \multirow{2}{*}{ SRISK - EPU } & \multirow{2}{*}{$\begin{array}{l}\text { Intercept, } \\
\text { no det. trend }\end{array}$} & \multirow{2}{*}{0} & 0 & 23.944 & 25.085 & 20.262 & 17.981 \\
\hline & & & 1 & 6.521 & 12.761 & 9.164 & 7.557 \\
\hline \multirow{2}{*}{ SRISK - PROPP } & \multirow{2}{*}{$\begin{array}{l}\text { Intercept, } \\
\text { no det. trend }\end{array}$} & \multirow{2}{*}{2} & 0 & 15.504 & 19.940 & 15.495 & 13.423 \\
\hline & & & 1 & 1.415 & 6.635 & 3.842 & 2.706 \\
\hline \multirow{2}{*}{ SRISK - TRADSB } & \multirow{2}{*}{$\begin{array}{l}\text { Intercept, } \\
\text { det. trend }\end{array}$} & \multirow{2}{*}{0} & 0 & 98.446 & 31.153 & 25.872 & 23.343 \\
\hline & & & 1 & 8.925 & 16.557 & 12.517 & 10.666 \\
\hline \multirow{2}{*}{ SRISK - BSHADOW } & \multirow{2}{*}{$\begin{array}{l}\text { Intercept, } \\
\text { det. trend }\end{array}$} & \multirow{2}{*}{1} & 0 & 16.669 & 19.940 & 15.495 & 13.430 \\
\hline & & & 1 & 2.346 & 6.635 & 3.842 & 2.706 \\
\hline \multirow{3}{*}{$\begin{array}{l}\text { SRISK - EPU } \\
\text { - PROPP }\end{array}$} & \multirow{3}{*}{$\begin{array}{l}\text { Intercept, } \\
\text { det. trend }\end{array}$} & \multirow{3}{*}{0} & 0 & 39.862 & 41.192 & 35.193 & 32.270 \\
\hline & & & 1 & 17.124 & 25.085 & 20.262 & 17.981 \\
\hline & & & 2 & 5.158 & 12.761 & 9.164 & 7.557 \\
\hline \multirow{4}{*}{$\begin{array}{c}\text { SRISK - EPU } \\
\text { - PROPP - TRADSB }\end{array}$} & \multirow{4}{*}{$\begin{array}{l}\text { Intercept, } \\
\text { det. trend }\end{array}$} & \multirow{4}{*}{2} & 0 & 48.177 & 54.685 & 47.856 & 44.493 \\
\hline & & & 1 & 26.775 & 35.466 & 29.798 & 27.066 \\
\hline & & & 2 & 10.475 & 19.940 & 15.495 & 13.430 \\
\hline & & & 3 & 0.184 & 6.635 & 3.842 & 2.706 \\
\hline \multirow{4}{*}{$\begin{array}{c}\text { SRISK - EPU } \\
\text { - PROPP - BSHADOW }\end{array}$} & \multirow{4}{*}{$\begin{array}{l}\text { Intercept, } \\
\text { det. trend }\end{array}$} & \multirow{4}{*}{2} & 0 & 54.369 & 61.265 & 54.078 & 50.525 \\
\hline & & & 1 & 30.163 & 41.192 & 35.193 & 32.270 \\
\hline & & & 2 & 14.415 & 25.085 & 20.262 & 17.981 \\
\hline & & & 3 & 5.633 & 12.761 & 9.164 & 7.557 \\
\hline
\end{tabular}

TABLE 3

Unit root and cointegration tests

Note: Lags based on Akaike, Hannah-Quinn and Schwarz Information Criteria on the vector- error correction model. Trends/ intercepts based on regressions on the residuals of the cointegrating relationship. 
point is January 2011 because that is when systemic risk becomes effectively non-zero, and also the data has become available for all banks in the sample. We apply the test on the log transformation of the series, with amounts in billion USD where applicable. The results show the existence of cointegration between all pairs, which implies co-movement between each couple of variables and is in line with Figures $4 \mathrm{a}$ and $4 \mathrm{~b}$. When the variables are grouped, the existence of at least one cointegrating relationship is also shown. However, a series of unreported VAR estimations and Granger causality tests using the first-differenced series showed no causality. Therefore, we conclude that there always is at least one cointegrating relationship at the levels of the time series and in order to infer causality we estimate the corresponding VECM models with one fewer lag than the VAR model, as defined by the Akaike, Schwarz and Bayesian Information Criteria. Similar to the Johansen tests, we estimate VECMs in pairs and groups of time series and examine long- and short-term causality relations. The results and specifications of each model can be found in Table 4.

Panel A in Table 4 reports the VECM results for the pairs of time series that are central to the paper. We are particularly interested on whether SRISK is affected by other indicators in the long- and short-run, the relationship between PROPP and the two shadow banking proxies, and whether bi-directional causality is present in the data. When SRISK is the dependent variable, the error correction term (ECT) is negative and statistically significant for all four pairs at either $1 \%$ or $5 \%$ significance level. This indicates a long-run causal relationship flowing from policy uncertainty, property prices and the shadow banking sector towards systemic risk. Moreover, the lagged terms of PROPP and EPU are statistically significant at 5\% and $10 \%$ significance levels, which demonstrates the casual relationship between variables in the short-run. This verifies our intuition that the reasons behind the recent and persistent increase in systemic risk can be traced to the increase in housing prices as well as the increased public concerns about economic policy, captured by news coverage. This co-movement is robust and stable, as demonstrated by the negative signs of the error correction terms which technically signifies convergence to the long-run equilibrium of the cointegration relationship. Importantly, the observed causal relationships are unidirectional for the housing prices and bank shadow indicators. When the pairs are reversed and SRISK becomes the independent variable in the VECM, the error correction terms are 
not statistically significant.

On the contrary, causality in the EPU/ SRISK and TRADSB/ SRISK pairs is bidirectional and only observed in the long-run, since only the ECTs are statistically significant. It must be noted that the ECT for TRADSB/ SRISK is positive, which signifies an unstable cointegration relationship. This result reappears when the VECM contains 3 and 4 variables and is robust across different model and lag specifications, which supports the importance of indicator construction for shadow banking. Our findings signify the need to reexamine the relationship between shadow banking and systemic risk in the future using a variety of measures. Finally, the PROPP/ TRADSB and PROPP/ BSHADOW pairs show that there is a long-run causal relationship flowing from both proxies of systemic risk to the property price index. However, there is no short-term causality since only the ECTs are statistically significant but the lagged terms are not. The results for the reversed pairs support uni-directional causality. It must be stressed that, with the exception of the positive error correction term for the TRADSB/ SRISK pair, all other results have a negative sign which shows a stable cointegration relationship and convergence to the long-run equilibrium.

Table 4, Panel B examines the simultaneous interplay between SRISK, PROPP and EPU. There is stable long- as well as short-run causality from economic policy uncertainty and property prices when they are jointly included in the model, as shown by the statistically significant and negative ECT and lagged terms. This strengthens our results for the pairs. There is no causality when PROPP becomes the dependent variable, but it is observed in the case of EPU. This further underlines that property prices and policy uncertainty jointly contribute to systemic risk and there is some evidence of systemic risk and property prices affecting policy uncertainty. Property prices appear to affect but not be affected by SRISK and EPU.

Finally, we conduct two 4-variable VECMs (Panels C and B), one for each shadow banking proxy, with all other variables present. In the SRISK/ EPU/ PROPP/ TRADSB group, the ECT is still negative and statistically significant, but only EPU shows short-term causality. The only other case where the ECT is statistically significant is when TRADSB is the dependent variable, but the sign is positive. SRISK also appears to affect shadow banking in the short-run. When the bank shadow indicator is used instead of traditional shadow bank- 

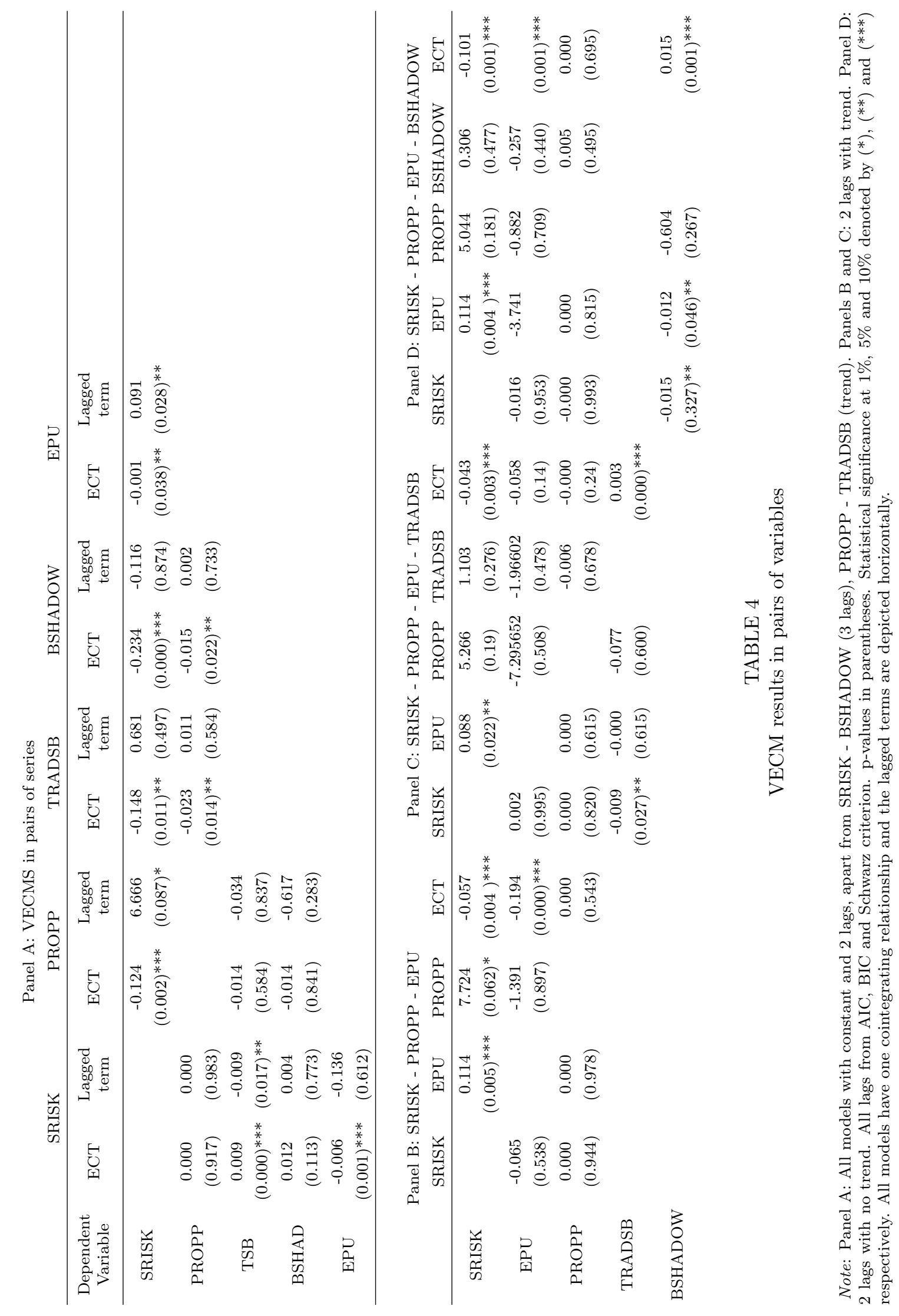
ing, the results are largely similar with some additional features. First, long-run causality is observed when EPU is the dependent variable. Second, when BSHADOW is the dependent variable, both SRISK and EPU exhibit short-run causality. No causality is detected in relation to property prices.

We therefore demonstrate an intricate network of interactions, where the influence of housing prices, shadow banking and economic policy uncertainty on systemic risk is persistent across different cases, both in the long- and the short-run. This shows that there is a robust causal relationship from all four proxies to SRISK, which validates our earlier intuition that an increase in systemic risk can be attributed to an increase in shadow banking activities, a rise in residential property prices and increased economic policy uncertainty. The results also suggest that systemic risk affects shadow banking when policy uncertainty and property prices are considered, but not in isolation. It is important to notice that the causal relationship between PROPP and SRISK shows that an increase in property prices leads to an increase in systemic risk, not the other way around. Economic policy uncertainty frequently appears to act both as a causal factor and the recipient of causal effects when all factors are present. Finally, both shadow banking proxies influence property prices when examined in isolation, but this relationship is not statistically significant in the short-run in the joint estimation.

Our results show a striking similarity with the well-documented pre-crisis patterns in many countries. The relationship between the US housing bubble, securitization of the US real estate loans and general accumulation of risk would typically be associated with a surge in asset prices prior to the outbreak of the financial crisis has been well documented. Our results indicate a similar story for the Chinese financial and real estate sectors. As discussed earlier, increased debt in both households and real estate firms leads to an increased need for financial resources and liquidity in order to cover the increased demand for housing and real estate. The Chinese shadow banking sector acts as a provider of such liquidity through maturity transformation of corporate debt. The findings also suggest a joint increase in systemic risk and economic policy uncertainty, as reflected by media coverage. The increase in uncertainty is quite pronounced after 2011, which covers the post-crisis asset bubble, the 2015-2016 period of market turbulence, the expansion of the shadow banking sector and the 
ongoing regulatory reforms in the financial sector.

\section{Interconnectedness}

In the case of a systemic event, the decline in the equity price of a distressed bank is likely to cause spillover effects to other institutions. Therefore, it would be beneficial to examine whether any relationships between the equity returns of the financial institutions in our sample match our earlier findings. We follow the methodology of Billio et al. (2012) and analyze Granger-causality networks between banks and re-examine whether the biggest institutions dominate the sector or, as our findings on SRISK showed, smaller banks appear to play an important role.

Figure 5 reports the network over the sample period between January 2012 and September 2018. The period is selected based on our SRISK results. Degree centrality and the ordering of the banks according to the number of connections can be found in Table 3. Figure 6 reports the evolution in the number of In + Out (IO) and In + Out - Other (IOO) connections and Figure 7 reports the Dynamic Causality Index. In both figures, a clear increase in the number and intensity of the causal relationships between the institutions in our sample can be seen. The difference between IO and IOO becomes most pronounced after mid-2016, where it solidifies.

Table 3 shows that none of the four biggest banks ranks at the top as either a bank that Granger-causes a high number of connections or with a very high overall number of connections. $\mathrm{ABC}$ is at the third and sixth place, respectively, while all others are at the middle of the list. As the size of the nodes in Figure 5 indicates, the banks which Grangercause the most connections are medium-sized banks. China Merchants Bank and China CITIC Bank occupy the first two places with 13 and 12 connections each, with ABC and Everbright in the third place with 11 connections. The other Big 4 rank even lower, since Ping An Bank, Chongqing Bank and Bank of Nanjing share the fifth place with 10 connections followed by Bank of China at the eight place with 11 Granger-caused connections. The 5 banks above $\mathrm{ABC}$ in the number of total connections also rank at the top positions in the number of causal relationships they cause. 


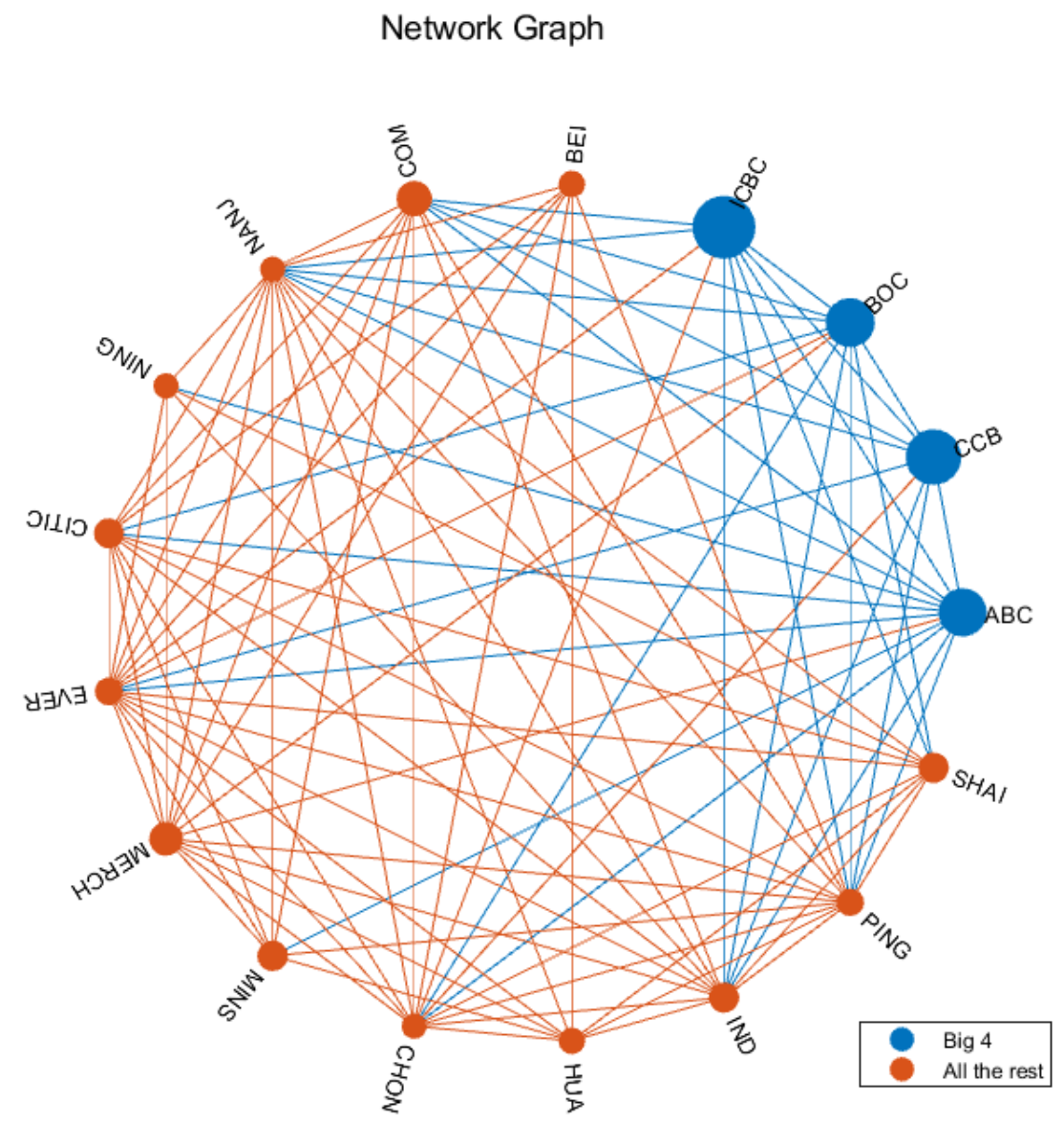

FIGURE 5

Bank interconnectedness and network of Granger-caused connections, 2012 - 2018

The Big 4 bank that ranks highest, Agricultural Bank of China, is at the sixth place together with Industrial Bank, Bank of Communications and China CITIC Bank, with 12 connections. Bank of Nanjing and Everbright are at the first place with 16 connections, followed by Ping An (15 connections) in the third, Chongqing (14) in the fourth and China Merchants Bank (13) in the fifth position. This indicates that smaller institutions have also become more interconnected, and a severe drop in their returns is likely to have a wider than believed impact in the banking sector. The SRISK results suggest that those banks also bear an increasing portion of systemic risk. Based on the causal relationships we detect, we conclude that a distress in a firm with many causal connections (typically a smaller institution in our sample) brought by a systemic event is likely to bring a fall in the share 


\begin{tabular}{ccccc}
\hline Bank & $\begin{array}{c}\text { Granger- } \\
\text { caused } \\
\text { connections }\end{array}$ & $\begin{array}{c}\text { Total } \\
\text { connections }\end{array}$ & $\begin{array}{c}\text { Ranking } \\
\text { (total } \\
\text { connections) }\end{array}$ & $\begin{array}{c}\text { Ranking } \\
\text { (Granger- } \\
\text { caused) }\end{array}$ \\
\hline Bank of Beijing & 1 & 7 & 16 & $=16$ \\
Shanghai Pudong Bank & 1 & 10 & $=11$ & $=16$ \\
Minsheng Bank & 2 & 8 & 15 & 15 \\
Industrial Bank & 3 & 12 & $=6$ & 14 \\
Bank of Ningbo & 4 & 6 & 17 & 13 \\
China Construction Bank & 6 & 9 & 14 & 12 \\
Bank of Communications & 7 & 12 & $=6$ & $=10$ \\
Industrial Commercial & 7 & 10 & $=11$ & 10 \\
Bank of China & 8 & 9 & 13 & 9 \\
Huaxia Bank & 9 & 11 & $=10$ & 8 \\
Bank of China & 10 & 16 & $=1$ & $=5$ \\
Bank of Nanjing & 10 & 14 & 4 & $=5$ \\
Chongqing Bank & 10 & 15 & 3 & $=5$ \\
Ping An Bank & 11 & 12 & $=6$ & $=3$ \\
Agricultural Bank of China & 11 & 16 & $=1$ & $=3$ \\
China Everbright Bank & 12 & 12 & $=6$ & 2 \\
China CITIC Bank & 13 & 13 & 5 & 1 \\
China Merchants Bank & & & & \\
\hline
\end{tabular}

TABLE 5

Network degree centrality results, 2012 - 2018

Note: Number of connections and firm ranking for Granger-caused connections and the total number of connections. The equality sign denotes the same number of connections between multiple banks.

price of that bank, which will affect a significant number of institutions to a lesser or greater extent. The direction of those spillover effects is inferred by the Granger causality detected, and we emphasise that the transition mechanism we are able to detect passes through returns and the stock market.

Similarly, Figures 6 and 7 demonstrate an increase of interconnectedness over time, which becomes most pronounced after mid-2016. Our findings agree with Wang et al. (2018), who also find some small firms to be systemically important due to their high level of in- or out-connectedness. The smaller banks in our sample have gradually become both the most connected and the most influential. Notably, they are not the recipients but the facilitators of causality both among themselves and with the four biggest banks. This is in line with 


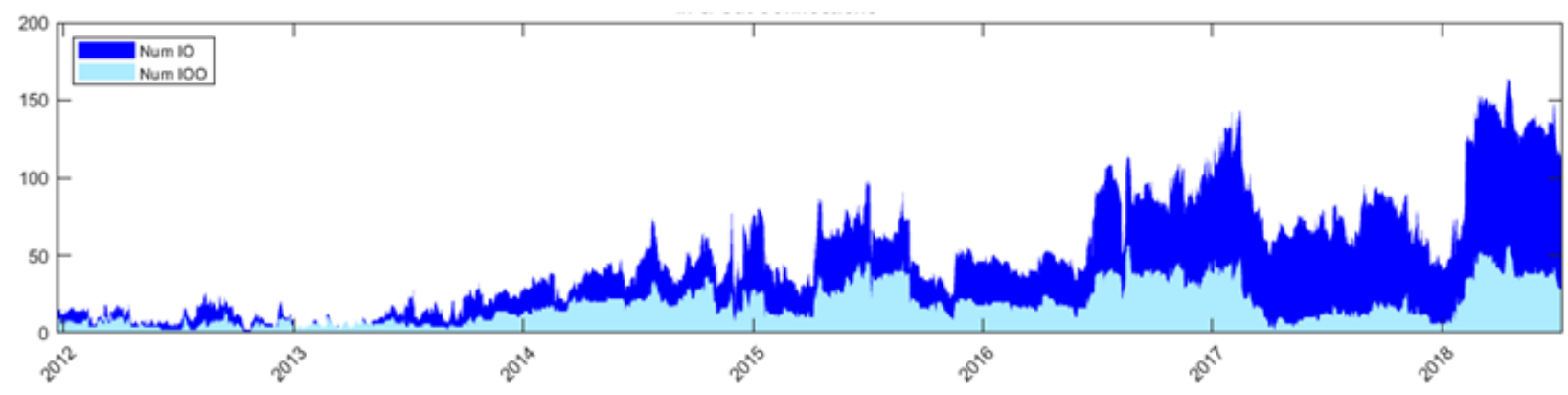

FIGURE 6

In+Out (IO) and In+Out-Others (IOO) connections over time

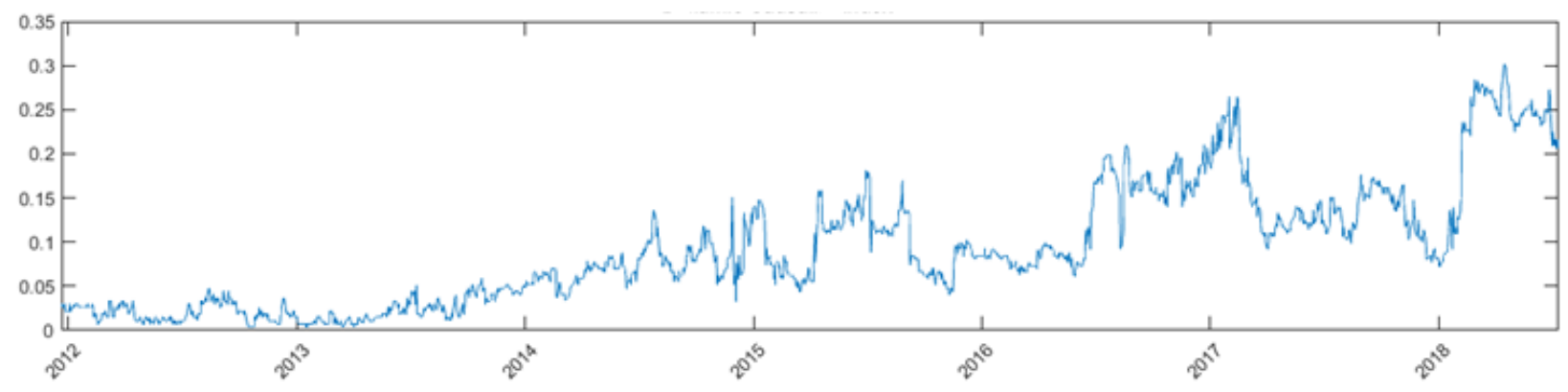

FIGURE 7

Dynamic Causality Index

our results on the importance of systemic risk and the relatively reduced role of the Big 4 in recent years. Figure 5 shows that mid-ranking banks are also the most central in the financial system. This matches our earlier observations and demonstrates how the smaller banks have begun to play a more important role in the Chinese financial system.

\section{Conclusion}

Our paper utilizes the SRISK measure of Brownlees and Engle (2016) and the network measures of Billio et al. (2012) in order to assess the stability of the Chinese banking system, in light of its massive post-crisis expansion. It also examines causality relationships between banks and between SRISK, the Chinese Economic Policy Uncertainty index, the Chinese real residential property prices index and two shadow banking proxies. 
Our first key finding is that Chinese banks that are not among the top largest banks are becoming increasingly significant as net contributors of systemic risk in the Chinese banking sector. The risk those institutions pose has become more significant in recent years, in terms of both individual capital requirements in the presence of a market shock, as well as in terms of network spillover effects among banks. Over the last decade, the contribution of the four biggest banks to the increase of systemic risk has been declining relative to that of their smaller counterparts, which have become more influential.

Our second key finding is that the increase in systemic risk can be attributed to all the factors mentioned above. The expansion of the shadow banking sector, the increase in housing prices and the rise in economic policy uncertainty contribute to the observed surge in systemic risk in recent years. This finding is robust and appears both when the indicators are paired and when examined in groups in the long-run. When shadow banking is excluded, there is causality from EPU and property prices to systemic risk in both the short- and the long-run. In addition, there is a causal relationship from shadow banking towards the property price index, which is a novel result. Finally, we report some evidence of bi-directional causality from SRISK to shadow banking and EPU. The results are clear on the causes of the increase in systemic risk and illustrate further interactions between the variables. The common relationship between fragility in the financial system and increasing real estate prices can, to some extent, be attributed to the expansion of shadow banking, which acts both as intermediary between the real estate and the banking sectors and a way for banks to offload risky assets and engage in otherwise regulated activities.

Thus, an international investor should be concerned about smaller Chinese banks and their effect in financial stability. Our main policy suggestion is that further regulatory changes need to focus not just on the biggest institutions, traditionally deemed as more systemically important, but also on smaller banks. Their increased exposure and connectedness may trigger a chain reaction with wider repercussions significantly larger than their individual size. As an indicator of the amount of additional funding that may be required in the case of distress, the maximum value of aggregate SRISK ( $\$ 864$ billion), is $6.32 \%$ of the Chinese nominal gross domestic product in 2018 (\$13.68 trillion). Although significant state ownership precludes a bankruptcy similar to that of Lehman Brothers, our findings suggest 
that both the number of potentially distressed banks and their capital requirements may be higher than currently assumed.

\section{References}

Acharya, V. V., Pedersen, L. H., Philippon, T., Richardson, M., 2017. Measuring systemic risk. The Review of Financial Studies 30 (1), 2-47.

Adrian, T., Brunnermeier, M. K., 2016. CoVaR. The American Economic Review 106 (7), 1705.

Allen, F., Qian, Y., Tu, G., Yu, F., 2019. Entrusted loans: A close look at China's shadow banking system. Journal of Financial Economics 133 (1), 18-41.

Baker, S. R., Bloom, N., Davis, S. J., 2016. Measuring economic policy uncertainty. The quarterly journal of economics 131 (4), 1593-1636.

Billio, M., Getmansky, M., Lo, A. W., Pelizzon, L., 2012. Econometric measures of connectedness and systemic risk in the finance and insurance sectors. Journal of financial economics 104 (3), 535-559.

Bloomberg News, 7 December 2018. China Needs Bailout, Capital Plans for Crisis Event: PBOC's Ma. Bloomberg.

Brownlees, C., Engle, R. F., 2016. SRISK: A conditional capital shortfall measure of systemic risk. The Review of Financial Studies 30 (1), 48-79.

Chen, M. S., Kang, J. S., 2018. Credit booms - is China different? IMF Working Paper, $\mathrm{WP} / 18 / 2$.

Chen, Q.-a., Du, F., 2016. Financial innovation, systematic risk and commercial banks stability in China: theory and evidence. Applied Economics 48 (41), 3887-3898.

Danıelsson, J., Shin, H., Zigrand, J., 2010. Risk appetite and endogenous risk. Available at http://www.lse.ac.uk/fmg/assets/documents/papers/discussion-papers/DP647.pdf.

Ding, D., Huang, X., Jin, T., Lam, W. R., 2017. Assessing China's residential real estate market. IMF Working Paper, 17/248.

Ehlers, T., Kong, S., Zhu, F., 2018. Mapping shadow banking in China: structure and dynamics.

Elliott, D., Kroeber, A., Qiao, Y., 2015. Shadow banking in China: A primer. Economic Studies at Brookings 3, 1-7.

Engle, R., Jondeau, E., Rockinger, M., 2014. Systemic risk in Europe. Review of Finance 19 (1), 145-190. 
Fang, L., Sun, B., Li, H., Yu, H., 2018. Systemic risk network of Chinese financial institutions. Emerging Markets Review 35, 190-206.

Fang, L., Xiao, B., Yu, H., You, Q., 2018. A stable systemic risk ranking in China's banking sector: Based on principal component analysis. Physica A: Statistical Mechanics and its Applications 492, 1997-2009.

Financial Stability Board, 5 March 2018. Global Shadow Banking Monitoring Report 2017. Bloomberg News.

Gang, J., Qian, Z., 2015. China's monetary policy and systemic risk. Emerging Markets Finance and Trade 51 (4), 701-713.

Hachem, K., 2018. Shadow banking in China. Annual Review of Financial Economics 10, 287-308.

Huang, Y., Luk, P., 2020. Measuring economic policy uncertainty in China. China Economic Review 59, 101367.

IMF, 2018. Global Financial Stability Report April 2018: A Bumpy Road Ahead. International Monetary Fund.

Jiang, H., Zhang, J., Sun, C., 2019. How does capital buffer affect bank risk-taking? new evidence from China using quantile regression. China Economic Review In press, available at https://doi.org/10.1016/j.chieco.2019.04.008.

Koss, R., Shi, X., 2018. Stabilizing China's housing market. IMF Working Paper, 18/89.

Lai, R. N., Van Order, R. A., 2019. Shadow banking and the property market in China. International Real Estate Review Forthcoming, available at http://dx.doi.org/10.2139/ssrn.2788012.

Lardy, N. R., Subramanian, A., 2011. Sustaining China's economic growth after the global financial crisis. Peterson Institute.

Li, J., Hsu, S., Qin, Y., 2014. Shadow banking in China: institutional risks. China Economic Review 31, 119-129.

Liao, M., Sun, T., Zhang, J., 2016. China's financial interlinkages and implications for interagency coordination. IMF Working Paper, 16/181.

Liu, L., Zhang, T., 2015. Economic policy uncertainty and stock market volatility. Finance Research Letters 15, 99-105.

MacKinnon, J. G., Haug, A. A., Michelis, L., 1999. Numerical distribution functions of likelihood ratio tests for cointegration. Journal of applied Econometrics 14 (5), 563-577.

OECD, 2018. Business and Finance Outlook 2018. OECD. 
People's Bank of China, 2014. China Financial Stability Report 2014. available at http://www.centerforfinancialstability.org/fsr/chn_fsr_201407.pdf.

Qian, X., Zhang, G., Liu, H., 2015. Officials on boards and the prudential behavior of banks: Evidence from China's City commercial banks. China Economic Review 32, 84-96.

Stolbov, M., Karminsky, A., Shchepeleva, M., 2018. Does economic policy uncertainty lead systemic risk? A comparative analysis of selected European countries. Comparative Economic Studies 60 (3), 332-360.

Sun, G., 2019a. China's shadow banking: bank's shadow and traditional shadow banking.

Sun, L., 2019b. Financial networks and systemic risk in China's banking system. Finance Research Letters Forthcoming, available at https://doi.org/10.1016/j.frl.2019.07.009.

Sun, X., Yao, X., Wang, J., 2017. Dynamic interaction between economic policy uncertainty and financial stress: A multi-scale correlation framework. Finance Research Letters 21, $214-221$.

Tian, G., Li, J., Xue, Y., Hsu, S., 2016. Systemic risk in the Chinese shadow banking system: A sector-level perspective. Emerging Markets Finance and Trade 52 (2), 475-486.

Turner, P., 2009. Testing for cointegration using the Johansen approach: are we using the correct critical values? Journal of Applied Econometrics 24 (5), 825-831.

Wang, G.-J., Jiang, Z.-Q., Lin, M., Xie, C., Stanley, H. E., 2018. Interconnectedness and systemic risk of China's financial institutions. Emerging Markets Review 35, 1-18.

Williams, G., 2018. The Evolution of China's Banking System, 1993-2017. Routledge.

Xu, Q., Chen, L., Jiang, C., Yuan, J., 2018. Measuring systemic risk of the banking industry in China: A DCC-MIDAS-t approach. Pacific-Basin Finance Journal 51, 13-31.

Yang, M., Jiang, Z.-Q., 2016. The dynamic correlation between policy uncertainty and stock market returns in China. Physica A: Statistical Mechanics and Its Applications 461, 92100.

Zhang, D., Cai, J., Dickinson, D. G., Kutan, A. M., 2016. Non-performing loans, moral hazard and regulation of the Chinese commercial banking system. Journal of Banking \& finance $63,48-60$.

Zhang, L., Hsu, S., Xu, Z., Cheng, E., 2018. Responding to financial crisis: Bank credit expansion with Chinese characteristics. China Economic Review In press, available at https://doi.org/10.1016/j.chieco.2018.09.014.

Zhu, N., Wu, Y., Wang, B., Yu, Z., 2019. Risk preference and efficiency in Chinese banking. China Economic Review 53, 324-341. 


\section{Tables and Figures}

\begin{tabular}{|c|c|c|c|c|c|c|c|}
\hline Variable & Obs. & $\mu$ & $\sigma$ & Min & Max & Frequency & \\
\hline MSCI-EM log-returns (\%) & 3,324 & 0.012 & 1.265 & -9.994 & 10.073 & Daily & \\
\hline Bank log-returns (\%) & 50,407 & 0.035 & 2.199 & -23.563 & 22.596 & Daily & \\
\hline $\begin{array}{l}\text { Bank Market } \\
\text { Capitalisation }\end{array}$ & 50,407 & 63.887 & 74.268 & 1.469 & 485.023 & Daily & \\
\hline Bank Total Assets & 747 & 772.739 & 927.905 & 8.792 & $4,223.731$ & Quarterly & \\
\hline $\begin{array}{c}\text { Bank Shareholders } \\
\text { Equity }\end{array}$ & 747 & 52.580 & 68.565 & 0.657 & 346.189 & Quarterly & \\
\hline $\begin{array}{c}\text { Real Residential } \\
\text { Property Price Index }\end{array}$ & 52 & 97.330 & 4.620 & 88.530 & 109.450 & Quarterly & \\
\hline $\begin{array}{c}\text { EPU Index } \\
\text { (Hong Kong-based) }\end{array}$ & 153 & 188.070 & 130.800 & 26.140 & 694.850 & Monthly & \\
\hline Bank & Abbreviation & \multicolumn{2}{|c|}{ Period } & Bank & \multicolumn{2}{|c|}{ Abbreviation } & Data Period \\
\hline $\begin{array}{c}\text { Agricultural } \\
\text { Bank of China }\end{array}$ & $\mathrm{ABC}$ & \multicolumn{2}{|c|}{$1 / 11-9 / 18$} & \multicolumn{2}{|c|}{$\begin{array}{l}\text { China } \\
\text { Everbright Bank }\end{array}$} & EVER & $1 / 11-9 / 18$ \\
\hline Bank of China & $\mathrm{BOC}$ & $1 / 07$ & $-9 / 18$ & Bank of $\mathrm{Na}$ & njing & NANJ & $1 / 08-9 / 18$ \\
\hline $\begin{array}{l}\text { China } \\
\text { Construction Bank }\end{array}$ & $\mathrm{CCB}$ & \multicolumn{2}{|c|}{$1 / 06-9 / 18$} & \multicolumn{2}{|c|}{$\begin{array}{c}\text { Bank of } \\
\text { Communications }\end{array}$} & $\mathrm{COM}$ & $1 / 06-9 / 18$ \\
\hline China CITIC Bank & CITIC & \multicolumn{2}{|c|}{$1 / 08-9 / 18$} & \multicolumn{2}{|c|}{ Chongqing Bank } & $\mathrm{CHON}$ & $1 / 11-9 / 18$ \\
\hline China Merchants Bank & MERCH & \multicolumn{2}{|c|}{$1 / 07-9 / 18$} & \multicolumn{2}{|c|}{ Huaxia Bank } & HUA & $1 / 06-9 / 18$ \\
\hline Bank of Ningbo & NING & \multicolumn{2}{|c|}{$1 / 08-9 / 18$} & \multicolumn{2}{|c|}{ Industrial Bank } & IND & $1 / 08-9 / 18$ \\
\hline $\begin{array}{c}\text { Industrial Commercial } \\
\text { Bank of China }\end{array}$ & $\mathrm{ICBC}$ & \multicolumn{2}{|c|}{$1 / 07-9 / 18$} & \multicolumn{2}{|c|}{$\begin{array}{c}\text { Shanghai } \\
\text { Pudong Bank }\end{array}$} & SHAN & $1 / 06-9 / 18$ \\
\hline Minsheng Bank & MINS & \multicolumn{2}{|c|}{$1 / 10-9 / 18$} & \multirow{2}{*}{\multicolumn{2}{|c|}{ Ping An Bank }} & PING & $1 / 06-9 / 18$ \\
\hline Bank of Beijing & BEI & $1 / 08$ & $-9 / 18$ & & & & \\
\hline
\end{tabular}

TABLE 6

Sample summary statistics

Note: Assets, market capitalization and equity values are in billion US dollars. 
Panel A: Augmented Dickey-Fuller unit root tests

\begin{tabular}{cccccccc}
\hline \multirow{2}{*}{ Variable } & AR Model & Lags & $\begin{array}{c}\text { Test } \\
\text { statistic }\end{array}$ & $\begin{array}{c}\text { Test stat. } \\
\text { (1st diff.) }\end{array}$ & $1 \%$ c.v & $5 \%$ c.v & $10 \%$ c.v \\
\hline SRISK & $\begin{array}{c}\text { Drift and } \\
\text { det. trend }\end{array}$ & 1 & -3.062 & -6.701 & -4.066 & -3.461 & -3.157 \\
EPU & $\begin{array}{c}\text { Drift and } \\
\text { det. trend }\end{array}$ & 2 & -2.327 & -6.750 & -4.067 & -3.462 & -3.157 \\
PROPP & $\begin{array}{c}\text { No drift, } \\
\text { no det. trend }\end{array}$ & 1 & -2.059 & -2.649 & -2.592 & -1.945 & -1.6139 \\
\hline
\end{tabular}

Note: All series in natural logarithms. SRISK is in billion $\$$ US, EPU is Hong Kong based EPU index, PROPP is the real residential property price index (monthly after cubic interpolation). EPU and PROPP indexed at January 2011. Lags based on correlogram of residuals. Tests without drift and with drift but no deterministic trend also fail.

Panel B: Johansen cointegration tests

\begin{tabular}{cccccccc}
\hline \multirow{2}{*}{ Variable } & Model & Lags & Rank & statistic & $1 \%$ c.v & $5 \%$ c.v & $10 \%$ c.v \\
\hline SRISK - CHN & Intercept, & \multirow{2}{*}{0} & 0 & 23.944 & 25.085 & 20.262 & 17.981 \\
& no det. trend & & 1 & 6.521 & 12.761 & 9.164 & 7.557 \\
\multirow{2}{*}{ SRISK - PROPP } & Intercept, & \multirow{2}{*}{2} & 0 & 15.504 & 19.940 & 15.495 & 13.423 \\
& no det. trend & & 1 & 1.415 & 6.635 & 3.842 & 2.706 \\
\hline
\end{tabular}

TABLE 7

Unit root and cointegration tests

Note: Lags based on Akaike, Hannan-Quinn and Schwarz Information Criteria on the vector- error correction model. Trends/ intercepts based on regressions on the residuals of the cointegrating relationship. 


\begin{tabular}{|c|c|c|c|c|}
\hline Bank & $\begin{array}{c}\text { Granger- } \\
\text { caused } \\
\text { connections }\end{array}$ & $\begin{array}{c}\text { Total } \\
\text { connections }\end{array}$ & $\begin{array}{c}\text { Ranking } \\
\text { (total } \\
\text { connections) }\end{array}$ & $\begin{array}{c}\text { Ranking } \\
\text { (Granger- } \\
\text { caused) }\end{array}$ \\
\hline Bank of Beijing & 1 & 7 & 16 & $=16$ \\
\hline Shanghai Pudong Bank & 1 & 10 & $=11$ & $=16$ \\
\hline Minsheng Bank & 2 & 8 & 15 & 15 \\
\hline Industrial Bank & 3 & 12 & $=6$ & 14 \\
\hline Bank of Ningbo & 4 & 6 & 17 & 13 \\
\hline China Construction Bank & 6 & 9 & 14 & 12 \\
\hline Bank of Communications & 7 & 12 & $=6$ & $=10$ \\
\hline $\begin{array}{c}\text { Industrial Commercial } \\
\text { Bank of China }\end{array}$ & 7 & 10 & $=11$ & 10 \\
\hline Huaxia Bank & 8 & 9 & 13 & 9 \\
\hline Bank of China & 9 & 11 & $=10$ & 8 \\
\hline Bank of Nanjing & 10 & 16 & $=1$ & $=5$ \\
\hline Chongqing Bank & 10 & 14 & 4 & $=5$ \\
\hline Ping An Bank & 10 & 15 & 3 & $=5$ \\
\hline Agricultural Bank of China & 11 & 12 & $=6$ & $=3$ \\
\hline China Everbright Bank & 11 & 16 & $=1$ & $=3$ \\
\hline China CITIC Bank & 12 & 12 & $=6$ & 2 \\
\hline China Merchants Bank & 13 & 13 & 5 & 1 \\
\hline
\end{tabular}

TABLE 8

Network degree centrality results, 2012 - 2018

Note: Number of connections and firm ranking for Granger-caused connections and the total number of connections. The equality sign denotes the same number of connections between multiple banks. 


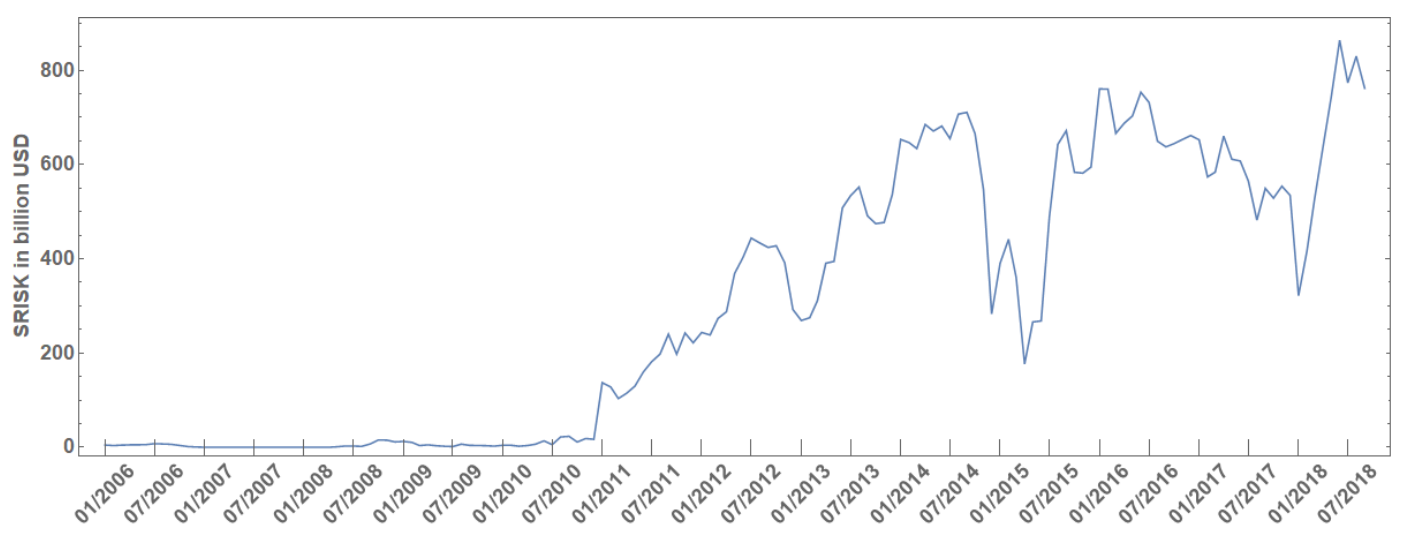

(a) Aggregate SRISK for all banks

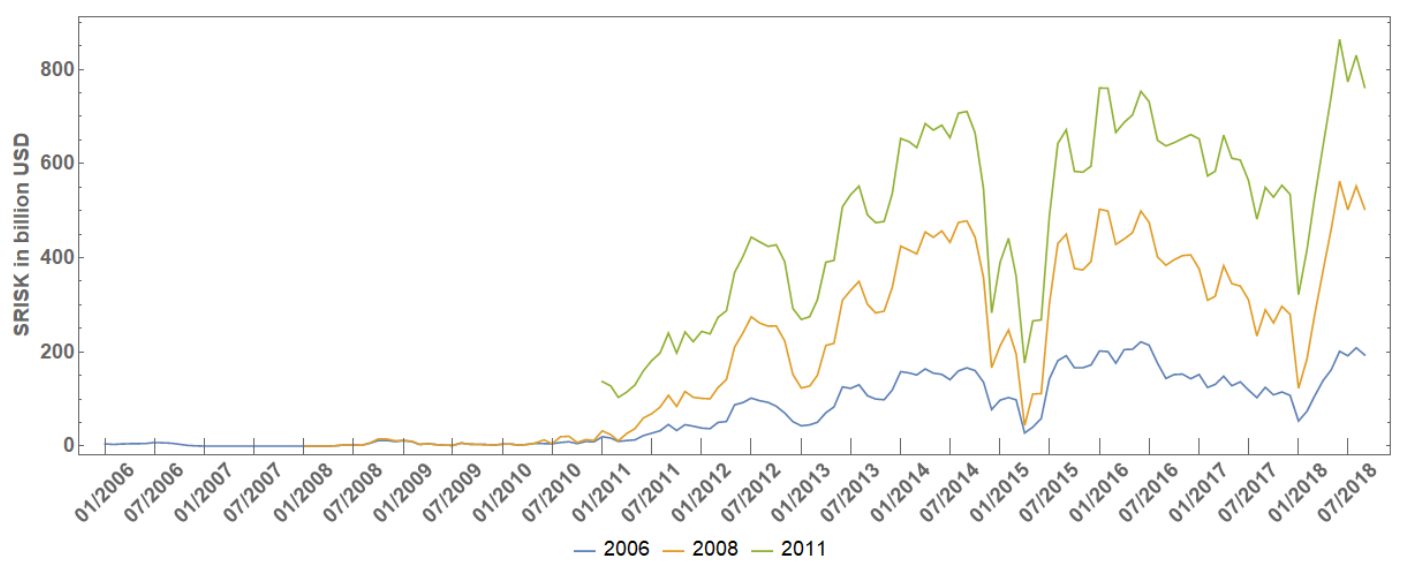

(b) Aggregate SRISK according to year of data availability. 2006: CCB,

BoComms, Huaxia, Ping An, Shanghai Pudong. 2008: BoC, ICBC, Merchants, CITIC, Beijing, Nanjing, Ningbo, Industrial. 2011: Minsheng, ABC, Everbright, Chongqing

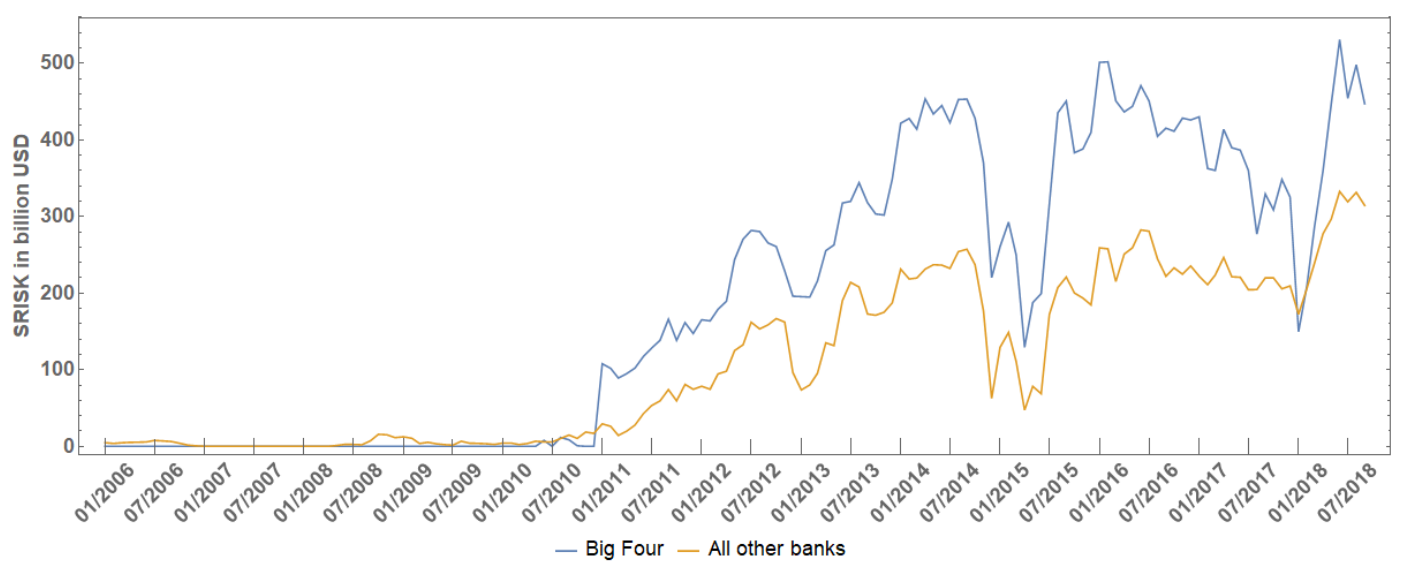

(c) Aggregate SRISK of the Big Four (CCB, BoC, ICBC, ABC) and all other banks

FIGURE 8 


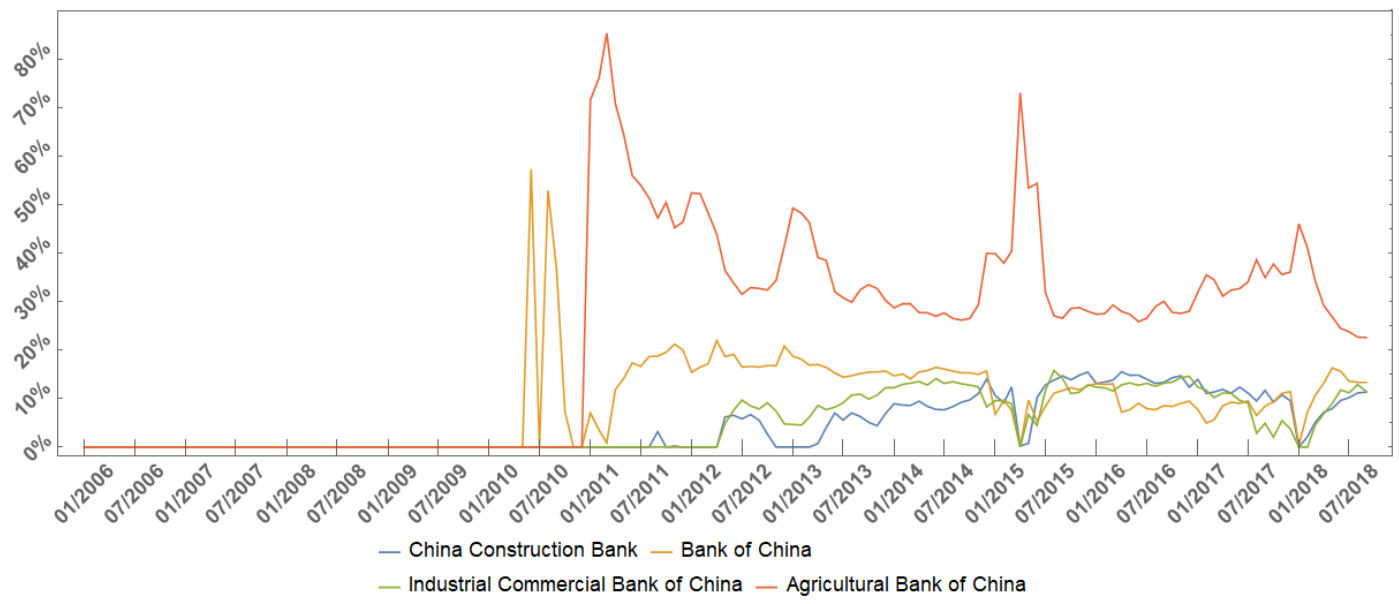

(a) Contribution (\%) of each of the Big Four banks to total SRISK

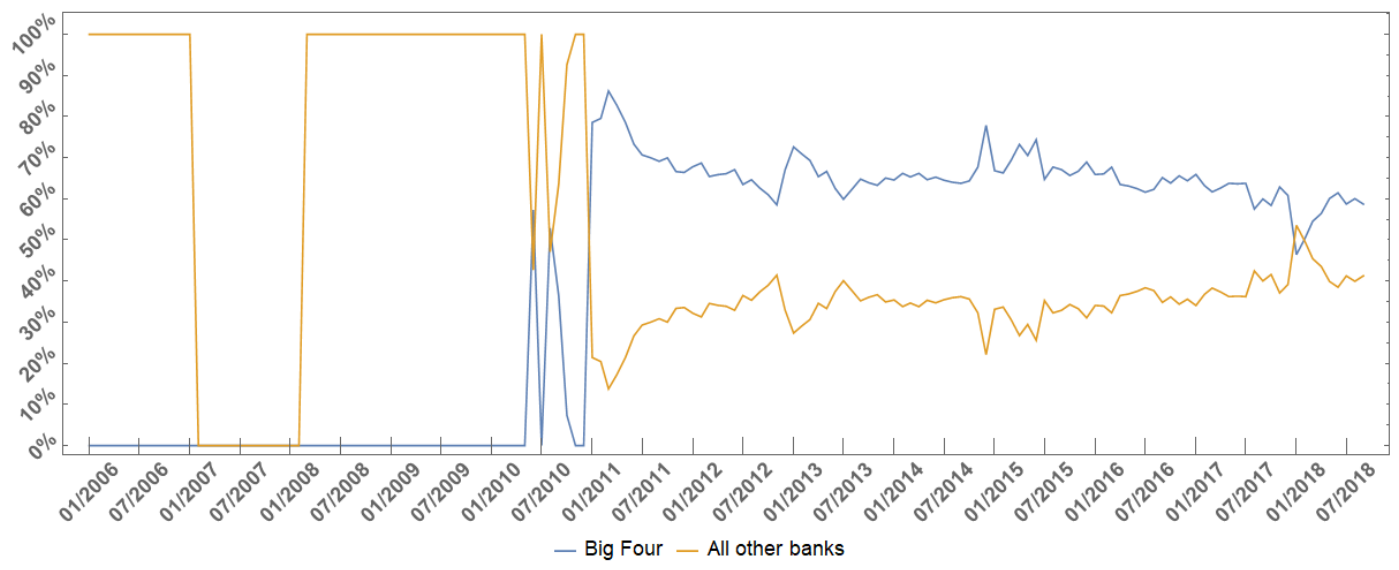

(b) Group contributions (\%) to total SRISK of the Big Four and all other banks

FIGURE 9 

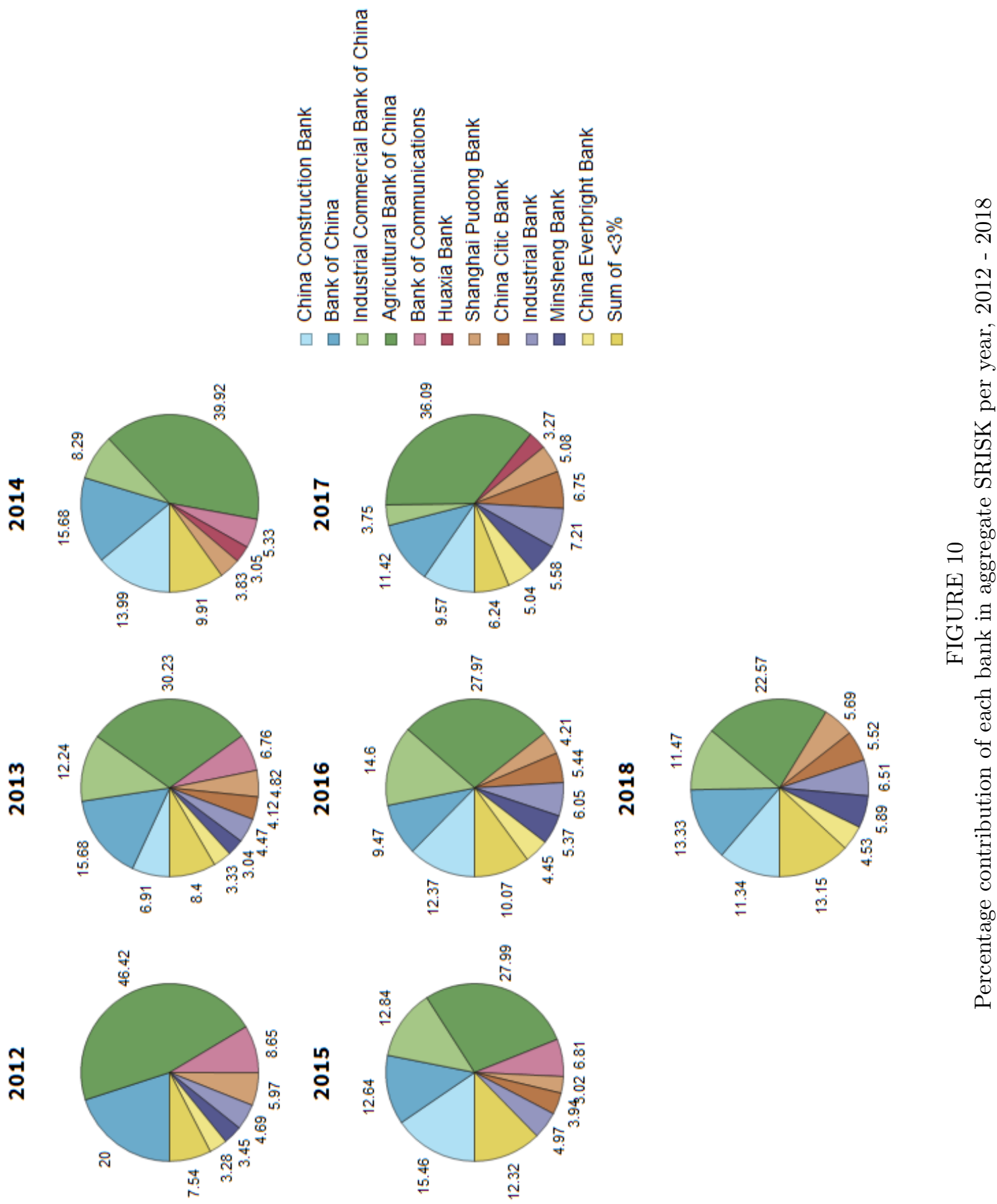

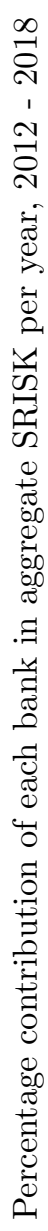




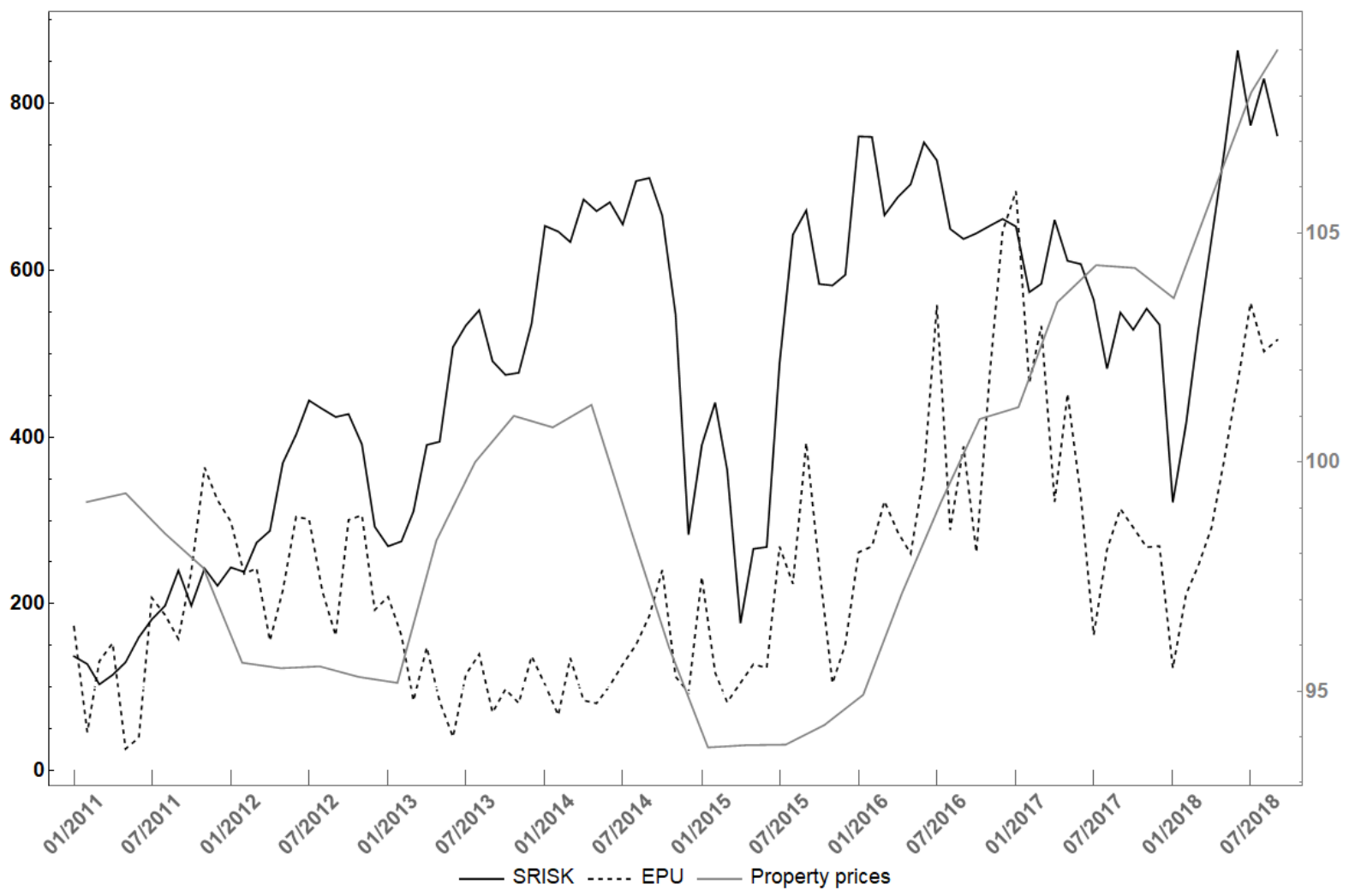

FIGURE 11

Original data of SRISK, EPU index (Hong-Kong based) (left axis, black) and real residential property prices index (right axis, grey), 1-2011 - 9-2018. 


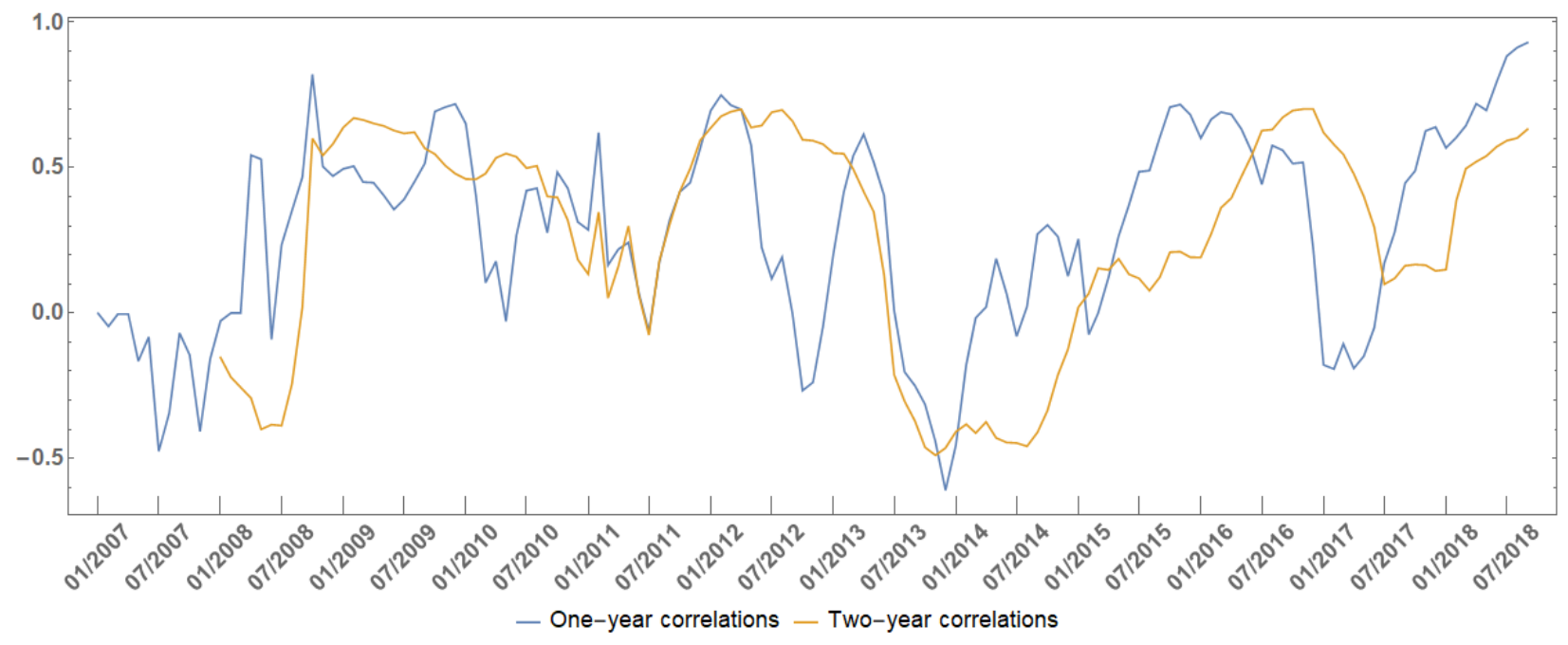

FIGURE 12

1- and 2-year correlations between SRISK and EPU, 2006 - 2018 


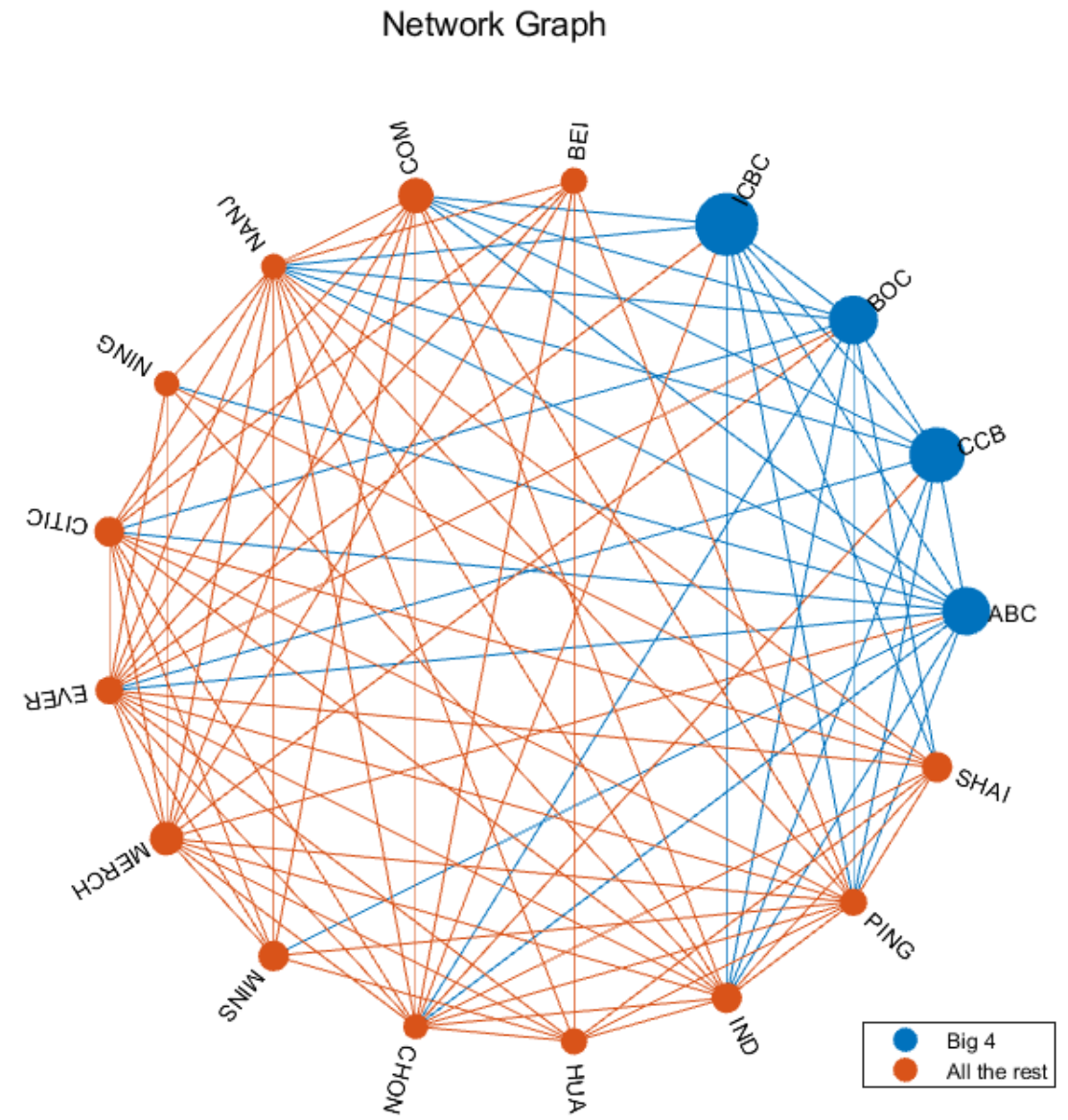

FIGURE 13

Bank interconnectedness and network of Granger-caused connections, 2012 - 2018

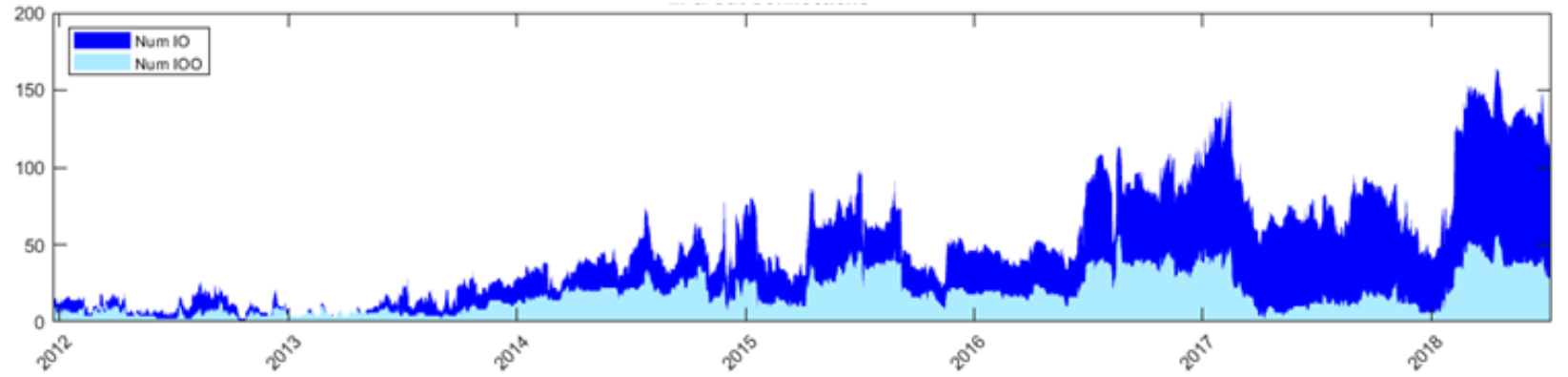

FIGURE 14

In+Out (IO) and In+Out-Others (IOO) connections over time 


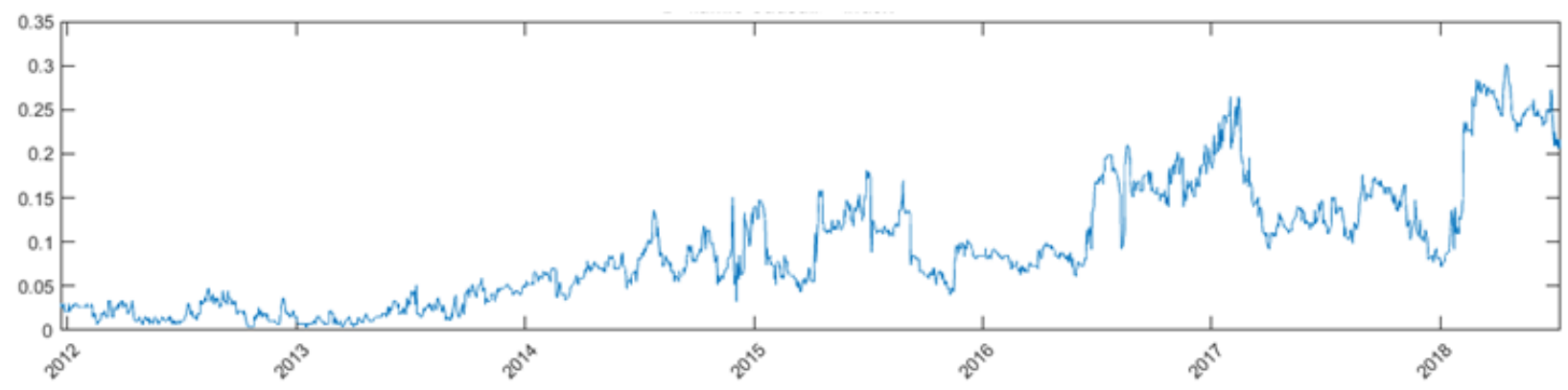

FIGURE 15

Dynamic Causality Index 